Yüzüncü Y1l Üniversitesi
Tarim Bilimleri Dergisi

Araştırma Makalesi (Research Article)

\title{
Bazı Yonca Çeşitlerinde (Medicago sativa L.) Biçim Zamanının Ot Verimi ve Kalitesi Üzerine Etkilerinin Saptanması**
}

\author{
Gürsel GÖKKAYA ${ }^{1}$, Adnan ORAK ${ }^{2 *}$
}

${ }^{1}$ T.C. Tarım ve Orman Bakanlığı, Tarım İşletmeleri Genel Müdürlüğü,06400 Ankara, Türkiye

${ }^{2}$ T.C. Tekirdağ Namık Kemal Üniversitesi, Ziraat Fakültesi, Tarla Bitkileri Bölümü, 59030 Tekirdağ, Türkiye ${ }^{1}$ https://orcid.org/0000-0002-8215-9124 ${ }^{2}$ https://orcid.org0000-0001-6588-8563

*Sorumlu yazar e-posta: aorak@nku.edu.tr

\section{Makale Bilgileri}

Geliş: 16.08 .2020

Kabul: 22.04.2021

Online Yayınlanma 30.06.2021

DOI: $10.29133 /$ yyutbd.781018

\section{Anahtar kelimeler}

ADF,

Biçim dönemi,

Ham protein oran1,

NDF,

Yeşil ot verimi,

Yonca.
Öz: Bu araştırma, farklı dönemlerde biçilen bazı yonca (Medicago sativa L.) çeşitlerinin ot verimi, verim özellikleri ve kalite değerlerini belirlemek amacıyla 2016-2018 yıllarında iki y1l süre ile Tekirdağ'da susuz koşullarda yürütülmüştür. Araştırma tesadüf blokları desenine göre faktöriyel düzende 3 tekrarlamalı olarak kurulmuş ve denemede Gözlü-1, Bilensoy 80, Prosementi, Plato ve Verko olmak üzere 5 farklı yonca çeşidi materyal olarak kullanılmıştır. Ot hasadı iki farklı (\%10 ve \%50 çiçeklenme) dönemde yapılmıştır. Araştırmadan elde edilen sonuçların değerlendirilmesi ile yıllar arasındaki farklar önemli bulunmuş ve ayrı ayrı incelenmiştir. İlk ve ikinci yıl ortalama değerlerine göre yonca çeşitlerinde bitki boyu değerlerinin $74.99 \mathrm{~cm}$ ile 46.98 $\mathrm{cm}$ aralığında değişim gösterdiği saptanmıştır. En yüksek yeşil ot verimi $4188.98 \mathrm{~kg} / \mathrm{da}$ ile Gözlü-1, en düşük verim ise $(3543.71 \mathrm{~kg} / \mathrm{da})$ ile Bilensoy 80 çeşidinde belirlenmiştir. Biçim zamanlarına bağlı olarak yeşil ot verimi farklılık göstermiştir. Yonca çeşitleri \%50 çiçeklenme döneminde (4353.24 kg/da) \%10 çiçeklenme dönemine göre $(3190.67 \mathrm{~kg} / \mathrm{da})$ daha fazla ot verimine sahip olmuştur. Kalite analizlerinde $\% 10$ ve $\% 50$ çiçeklenme zamanında yapılan biçimlerde protein oranı 1. yıl \% 21.80-21.36, ikinci y1l \% 22.73-2098; ADF oran1 1.y1l \% 40.15-42.47, 2. Y11 \% 39.60-43.25; NDF oran1 1. y11 \%40.9643.00, 2.y1l \%39.95-47.22; NYD 1. y1l 124.78-127.43, 2.y1l \%108.72-138.83 olarak bulunmuştur.

\section{Determination of The Effects of Cutting Time on Forage Yield and Quality in Some Alfalfa (Medicago sativa L.) Varieties}

\section{Article Info}

Received: 16.08.2020

Accepted: 22.04.2021

Online Published 30.06.2021

DOI: $10.29133 /$ yyutbd.781018

Keywords

ADF,

Harvest stage,

Crude protein ratio,

NDF.

Fresh forage yield,

Alfalfa.
Abstract: This study was conducted to determine effect of harvest times on yield and yield components of alfalfa (Medicago sativa L.) varieties in Tekirdağ conditions without irrigation between 2016-2018. The study was carried out in randomized block design with three replications. Gözlü-1, Bilensoy 80, Prosementi Bologna, Plato and Verko varieties was used as material, plants were harvested in two different flowering stages (\%10 and \%50). In two years statistical results, the characters of the study has significant differences and first year has higher results more than second year. According to statistical analyses years has significant differences and years was examined separately. In two years results plant height varied between $74.99-46.98 \mathrm{~cm}$. Highest fresh forage yield was determined from variety Gözlü-1 (4188.98 kg/da), lowest fresh forage yield was determined from variety Bilensoy-80 (3543.71 kg/da). Fresh forage yield varied belongs to harvest stage. Alfalfa varieties had higher fresh forage yield at 
$50 \%$ flowering period (4353.24 $\mathrm{kg} / \mathrm{da})$ compared to $10 \%$ flowering stage (3190.67 kg/da). According to forage quality analyses, protein content was determined between $21.80-21.36 \%$ in first year and $22.73-20.98 \%$ in second year at \% 10 and \%50 flowering harvest time. The ADF was determined 40.15$42.47 \%$ in first year and 39.60-43.25 \% in second year; the NDF was determined 40.96-43.00 \% in first year and 39.95-47.22 \% in second year; the RFV was determined $124.78-127.43 \%$ in first year and $108.72-138.83 \%$ in second year at same harvest times.

**Bu çalışma Gürsel Gökkaya’nın yüksek lisans tezinin bir bölümünü kapsamaktadır.

\section{Giriş}

Yonca, ülkemizde yem bitkileri içerisinde en fazla ekim alanına sahip baklagil yem bitkisidir. 2019 yılı rakamlarına göre Türkiye'de yonca ekim alanı 641.213 ha'dır (TÜİK, 2020). Tarımda sürdürülebilir hayvancıllğın temel bileşeni olarak kaliteli kaba yem üretimi için oldukça önemli bir bitki olup, Türkiye İstatistik Kurumu (TÜIK) 2019 yılı verilerine göre toplam yem bitkileri ekim alanının yaklaşı \% 30.76'sını, yeşil yem üretiminin ise \% 32.45'ini oluşturmaktadır. Trakya bölgesi 2.4 milyon ha yüz ölçümü, 1.2 milyon ha işlenebilir verimli arazi varlığı ile önemli bir bölgemizdir. Büyük baş hayvan varlığının neredeyse tamamının kültür ve melez ırk olduğu söylenebilir. Ancak kaba yem kaynakları konusunda sorunların yaşandığı bilinmektedir. Trakya bölgesinde ihtiyaç duyulan kaba yem, çayır mera ve yem bitkileri ekim alanlarının sınırlı olması nedeni ile karşılanamamaktadır. Bölge ölçeğinde değerlendirildiğinde yüzölçümün \% 9.81'ini çayır ve mera alanları oluşturmaktadır. Bu oran ülke genelinde \% 18.74'tür (TÜİK, 2020). Tekirdağ, Edirne ve Kırklareli illerinin mevcut hayvan varlığının (494.026 BBHB) ihtiyacı olan kaliteli kaba yem ihtiyacının 1.2 milyon ton olduğu ortaya çıkmaktadır (TÜİK, 2020). Çayır mera alanlarının sınırlı olması nedeni ile yem bitkileri üretimine ağırlık verilmesi zorunlu hale gelmiştir. Tek yıllık baklagil yem bitkileri yanında yüksek verim potansiyeline sahip çok yıllık baklagil yem bitkisi türleri de tercih edilmeye başlanmıştır. Yonca verim potansiyeli ve adaptasyon yeteneğinin yüksek olması nedeni ile öne çıkmıştır. Islah edilen yonca çeşitlerinin yoğunluğu konuya verilen önemi göstermektedir. Yapılan çalışmalarda yoncanın protein içeriği ve kalitesinin çeşitler arasında fazla değişim göstermediği, biçim zamanı, yıllık biçim sayısının önemli olduğu vurgulanmaktadır (Maurie`s, 2004; Orloff ve Putnam, 2007; Putnam ve ark., 2008; Veronesi ve ark., 2010).

Yonca bal üretiminde önemli kaynak olması, biyolojik çeşitliliği koruması ve tohum verimini artırması nedeni ile önemlidir (Duke, 1983). Ayrıca köklerindeki bakteriler aracılı̆̆ ile havanın serbest azotunu toprağa kazandırması ile toprak organik maddesinin zenginleşmesine yardımcı olmaktadır. Yonca sulu koşullarda çok kez biçilebilen ve yüksek ot verimine sahip olması yanında, kuru şartlarda yetiştirildiğinde su kullanım etkinliği yüksek bir bitkidir (Undersander ve ark., 2011; Orloff ve ark., 2015). Derine giden kökleri ile kurağa ve yüksek sıcaklığa toleranslıdır. Toprak reaksiyonu $(\mathrm{pH})$ 6.5-7.5 olan topraklarda iyi gelişmekte ve tuzluluğa kısmen tolerans göstermektedir. Farklı iklim koşullarında sulanmadan üç veya dört kez biçilmektedir. Yoncada yüksek verim 2. veya 3. yılda alınmaktadır.

Yapılan araştırmalarda; Chen ve ark. (2013), Kuzey Çin-Songnen ovasında yoncada en uygun biçim aralığını $(30,40,60$ gün) belirlemek amacı ile 2 yıl süre ile yürüttükleri çalışmada; biçim aralığının (30, 40, 60 gün) artması ile bitki boyunun her iki yılda da; sırası ile 52.5-51.3 cm, $65.66 \mathrm{~cm}$ ve 75.6-76.6 cm arasında değiştiğini belirtmişlerdir. Ankara ve Isparta'da sulanan koşullarda yürütülen araştırmada (Yüksel ve ark., 2016) 1 aday, 5 tescil edilmiş yonca çeşidi materyal olarak kullanılmıştır. Bitki boyunun Ankara lokasyonunda 48.00-73.38 cm, Isparta lokasyonunda ise 60.88-75.75 cm arasında değiştiği bildirilmiştir. Ankara koşullarında sulu koşullarda 2 yıl süre ile yürütülen başka bir araştırmada ise yonca; 5 farklı zamanda (Vejetatif, tomurcuklanma, \%10 çiçeklenme ve çiçeklenme dönemi sonu ve bakla bağlama) biçilmiş ve sırası ile 34.0, 41.4, 57.3, 81.9 ve $83.1 \mathrm{~cm}$ boy ölçümleri belirlenmiştir. Bu araştırmada biçim zamanının gecikmesi ile bitki boyunun yükseldiği saptanmıştır (Mutlu, 2019).Altınok ve Karakaya (2002), Ankara ekolojisinde susuz koşullarında 3 yıl süre ile yürüttükleri araştırmada \%10-20 çiçeklenme döneminde biçtikleri yoncanın yeşil ot veriminin birinci y11 $1869 \mathrm{~kg} / \mathrm{da}$, ikinci y1l $4071 \mathrm{~kg} /$ da üçüncü y1l ise $3839 \mathrm{~kg} /$ da olduğunu belirlemişlerdir. Yine Ankara koşullarında yürütülen araştırmada, farklı biçim zamanlarının (Vejetatif, tomurcuklanma, \%10 
çiçeklenme ve çiçeklenme dönemi sonu ve bakla bağlama) yonca otunun verim ve kalite özelliklerine olan etkisi araştırılmış, yeşil ot veriminin biçim dönemlerine bağlı olarak sırası ile 2892.5, 3460.8, 4129.7, 4732.2, $4275.7 \mathrm{~kg} / \mathrm{da}$; olduğu, en yüksek verimin çiçeklenme dönemi sonunda alındığ1 saptanmıştır (Mutlu 2019).Weir ve ark. (1960), farklı gelişme dönemlerinde yapılan biçimin yoncanın verim, kalite ve dayanıklılığını belirlemek için yürüttükleri çalışmada, biçimleri 3 yıl süreyle tomurcuklanma öncesi, tomurcuklanma, \%10 çiçeklenme ve \%50 çiçeklenme zamanında yapmışlar. Deneme sonucunda, en yüksek toplam kuru madde veriminin, \%50 çiçeklenme zamanında biçilen yonca parselinden alındığ 1 , en yüksek protein ve sindirilebilir besin maddesi veriminin ise $\% 10$ çiçeklenmede belirlemişlerdir. Kıraç koşullarda yürütülen çalışmalarda yoncadan 1-2 biçim ve 200$250 \mathrm{~kg} / \mathrm{da}$ kuru ot verimi aldığ 1 belirtilmektedir (Açıkgöz, 2001). Ankara kıraç koşullarında 7 farklı yonca çeşidi ile yürüttüğü araştırmada (Altınok ve Karakaya, 2002) \%10-20 çiçeklenme döneminde yapılan biçimde kuru madde veriminin birinci yıl $651 \mathrm{~kg} / \mathrm{da}$, ikinci y1l $1297 \mathrm{~kg} / \mathrm{da}$, üçüncü yıl ise 1226 $\mathrm{kg}$ /da olduğunu saptamışlardır. Haymana'da (Ankara) sulu koşullarda yapılan çalışmada; en yüksek kuru ot veriminin $1004.60 \mathrm{~kg} / \mathrm{da}$ ile Gözlü çeşidinde, en düşük ise $830.40 \mathrm{~kg} / \mathrm{da}$ ile Elçi çeşidinde olduğu belirlenmiş̧ir. En uygun biçim zamanının belirlenmesi amacı ile yürütülen araştırmada; en yüksek kuru ot verimi $1227.10 \mathrm{~kg} / \mathrm{da}$ ile tam çiçeklenme döneminde, en düşük ise $605.80 \mathrm{~kg} / \mathrm{da}$ ile vejetatif dönemde elde edilmiştir (Mutlu, 2019).

Yonca otunun kaliteli olması için, protein oranının yüksek olması arzu edilmektedir. Yonca kuru otunun kaitesini etkileyen faktörlerin başında hasat zamanı gelmektedir (Açıkgöz ve Demirel, 2021). Weir ve ark. (1960) farklı dönemlerde biçilen (Tomurcuklanma öncesi, \%10 çiçeklenme, \%50 çiçeklenme dönemi) yoncanın yüksek protein ve sindirilebilir besin maddesinin \%10 çiçeklenme döneminde, en yüksek protein oranının ise tomurcuklanma döneminde alındığını belirlemişlerdir. Biçim sıklığının yonca otunun protein oranına etkisinin araştırıldığı çalışmada $25,30,35$ ve 40 gün biçim aralıklarında, ham protein oranının, \%25.5, 26.6, 27.5, 28.2 değişim gösterdiğini bildirmiştir (Probst, 2008). Chen ve ark. (2013), Kuzey Çin-Songnen ovasında yoncada en uygun biçim aralığını (30, 40, 60 gün) belirlemek amacı ile 2 yıl süre ile yürüttükleri çalışmada; en yüksek ot verimi ve kalitesine 40 gün ara ile yapılan biçimlerde ulaşıldığını bildirmişlerdir. Ayrıca; protein oranının ilk yılda olduğu gibi (30 gün, \% 25; 40 gün, \%22.56; 60 gün, \%18.42), ikinci yılda da (30 gün, \%25.33; 40 gün, \%22.70; 60 gün, \%18,62) biçim zamanı geciktikçe protein oranının azaldığını saptamışlardır. Başka bir araştırmada Mala ve Fadlalla (2013), İlk biçimden itibaren 7 gün sonra başlayarak sonraki biçim başlayana kadar (21-30 gün) devam eden süreçte, 3 günde bir yaptıkları biçimde alınan örneklerin protein oranının \% 26'dan \% 17'ye gerilediğini belirlemişlerdir. Sırbistan'da yürütülen çalışmada Milic ve ark. (2014) 2010-2011 yıllarında iki farklı lokasyonda 5 yonca çeşidiyle yaptıkları denemede, kaliteli en yüksek ot veriminin y1lda dört (geç çiçeklenme döneminde) ile beş (erken çiçeklenme döneminde) kez yapılan biçimde olduğunu belirlemişlerdir. Yılda üç kez yapılan biçimde verimin düştüğünü, çeşitlerin genetik potansiyelleri ile çevre koşullarını tam olarak değerlendiremediklerini ortaya koymuşlardır. Doohong (2016), yoncada yüksek verim ve kaliteli ot üretimi için biçim aralığının önemli olduğunu, bu amaçla yürüttükleri araştırmada 28, 35, 42 ve 49 gün ara ile yaptıkları biçimlerde, ham protein oranının hasadın gecikmesi ile azaldığını (ilk yıl \% 29.726.0-25.9-23.9; ikinci y11 \% 30.5-27.9-22.8-22.2) bildirmiştir. Mutlu (2019) yonca otunun protein oranının vejetatif dönemde \% 25.5, tomurcuklanma döneminde \% 25.0, \% 10 çiçeklenme döneminde $\%$ 24, tam çiçeklenme döneminde \% 23.2, meyve bağlama döneminde ise \% 22.6 olduğunu, en uygun biçim zamanının tam çiçeklenme döneminde olduğu belirtilmiştir. Ancak biçimin \% 50 çiçeklenme döneminde yapılması ile daha kaliteli ot elde edileceğini vurgulamıştır.

NDF oranı hücre duvarının ne kadarının sindirilebileceğini belirleyen önemli bir kalite indikatörüdür (Marsalis ve ark., 2009) ve NDF'yi oluşturan selüloz, hemiselüloz ve ligninin ruminantlar tarafından sindirimi oldukça zordur (Mertens, 2011). Yüksek kaliteli yonca otu üretimi için NDF içeriğinin \% 40' $\mathrm{n}$, ADF içeriğinin ise \% 31'in altında olması gerekmektedir (Redfearn ve Zhang, 2011; Kazemi ve ark., 2012).Yoncanın tam çiçeklenme döneminde sınır değerlerin NDF içeriğinde \% 53, ADF içeriğinde ise \%4 1 olduğunu açıklayan Dunham (1998), yüksek sindirilebilirlik için bunun önemli olduğunu belirtmiştir.Katić ve ark., (2009), NDF ve ADF içerikleri bakımından çeşitler arasındaki farkın yonca çeşitlerinin sahip olduğu genetik yapıdan kaynaklandığını belirtmişlerdir.Probst (2008) 2006-2007 y1llarında iki lokasyonda 5 yonca çeşidiyle, dört farklı biçim sıklığının $(25,30,35,40$ gün) yoncanın NDF oranına etkisinin araştırıldığ çalışmada \% 37.6, 38.0, 38.0, 39.3 oranları belirlenmiştir. Yoncanın ot verimi ve kalitesini belirlemek amacı ile Çin'de yapılan 
bir araştırmada (Chen ve ark., 2013) en düşük NDF oranının 30 gün ara ile yapılan biçimlerde alındığını 40 ve 60 gün ara ile yapılan biçimlerin bunu izlediğini bildirmişlerdir. Doohong (2016), yoncanın 28, 35, 42 ve 49 gün aralıklarla yapılan biçimde ilk yıl NDF oranlarının \% 27.7-30.4- 32.734.9, ikinci yıl ise \% 33.3-34.2-44.1-45.5 değişime sahip olduğunu bildirmiştir. Mutlu (2019) Ankara koşullarında sulu koşullarda yürüttüğü çalışmasında; farklı yonca çeşitlerinin farklı dönemlerde hasat edilmesi ile elde edilen otun NDF oranının tomurcuklanma öncesinde (Vejetatif dönem) \% 32.7, tomurcuklanma döneminde \% 33.5, \% 10 çiçeklenme döneminde \% 34.1, tam çiçeklenme döneminde\% 36.2, meyve bağlama döneminde ise \% 35.6 olarak bildirmiştir.

Çin'de iki y1l süre ile yürüttüğü araştırmada Doohong (2016) yoncanın 28, 35, 42 ve 49 gün ara ile biçilmesinin ADF oranını artırdığını (ilk yıl \% 21.5-24.0-25.5-27.7; ikinci yıl \% 25.4-27.935.1-35.2) saptamıştır. Probst (2008), 2006-2007 yıllarında iki lokasyonda 5 yonca çeşidiyle yaptığ1 araştırmada, dört farklı biçim sıklığının $(25,30,35,40$ gün) yoncanın ADF oranına etkisinin araştırıldığı araştırmada \% 25.5, 26.6, 27.5, 28.2 oranları belirlenmiştir. Ankara koşullarında sulu koşullarda yapılan çalışmada (Mutlu, 2019); farklı yonca çeşitlerinin farklı dönemlerde hasat edilmesi ile elde edilen otun ADF oranının tomurcuklanma öncesinde (Vejetatif dönem) \%47.1, tomurcuklanma döneminde \% 47.8, \%10 çiçeklenme döneminde \% 48.3, tam çiçeklenme döneminde $\%$ 50.8, meyve bağlama döneminde ise \% 50.3 olarak bildirmiştir. Yonca otunun kalitesinin belirlenmesi amacı ile geliştirilen nispi yem değerini (NYD) Probst (2008), 2006-2007 yıllarında iki lokasyonda 5 yonca çeşidiyle yaptığı araştırmada, dört farklı biçim sıklı̆̆ının $(25,30,35,40$ gün) yoncanın NYD etkisini araştırdığ 1 çalışmada 172.2, 167.4, 165.8, 159.1 olarak belirlemiştir. Çin'de yürütülen başka bir araştırmada ise (Doohong, 2016), yoncanın 28, 35, 42 ve 49 gün ara ile biçilmesinin nisbi yem değerini (ilk y1l 245-220-205-182; ikinci y1l 195-184-131-125 ) önemli düzeyde düşürdüguünü açıklamıştır. Ankara'da Haymana koşullarında yapılan araştırmada, yonca çeşitlerinin farklı dönemlerde hasat edilmesi ile elde edilen otun nisbi yem değerinin (NYD) tomurcuklanma öncesinde (Vejetatif dönem) 162.5, tomurcuklanma döneminde 160.9, \% 10 çiçeklenme döneminde 157.5, tam çiçeklenme döneminde 145.4, meyve bağlama döneminde ise 147.2 olarak bildirilmiştir (Mutlu, 2019). Yonca ile ilgili yapılan araştırmalarda ele alınan karakterler ot kalitesinin belirlenmesinde önemli ve yol gösterici durumunda olduğu anlaşılmaktadır. Yonca dünyada ve ülkemizde kabayem kaynağı olarak yetiştirilen baklagil yem bitkilerinin başında gelmektedir. Hayvansal üretimde işletmelerin karlı olabilmesi için ihtiyaç duydukları kaba yemin en az \% 60'ını kendi imkânları ile üretmeleri önerilmektedir. Son 50 yılda kültür ırkı ve melez hayvan üretim bölgesi olarak kabul edilen Trakya bölgesi verimli toprakları ve uygun iklimi nedeni ile buğday ve ayçiçeği tarımının yoğun olduğu, kuru tarım bölgesidir. Büyükbaş hayvan varlığının neredeyse tamamı yüksek verim potansiyeline sahip kültür ve melez 1rklardan oluşmuştur. Mevcut hayvan varlığının ihtiyacı olan kaba yem bölge çayır mera alanları ile tarla tarımı içinde yer alan yem bitkileri üretiminden karşılanmaktadır. 1980'li yılların başından itibaren ekilmeye başlanan ve giderek artan ekim alanı ile Macar fiği yanında yem bezelyesi ve yaygın fiğ gibi türler ekim nöbetine girmiş ve üretici tarafından benimsenmiştir. Tarlayı bir yıl içinde terk eden ve $10 \mathrm{~kg} / \mathrm{da}$ 'a varan organik azotu toprağa bağlayan tek yıllık baklagiller tercih edilmiştir. Yakın zamanda hayvansal ürün fiyatlarındaki yükselişle birlikte verilen teşviklerin artması tarımla ilgisi olmayan sektörlerinde ilgisini çekmiştir. Bölgede besi ağırlıklı çiftlikler kurulmuş dolayısı ile kaba yem ihtiyacı artmıştır. Çayır mera alanlarının sınırlı olduğu bölgede yem bitkileri üretimine ilginin artması ile birlikte yonca ekimi de artmıştır. Son yıllarda Orta Anadolu'dan getirilen yonca otunun ticarette ciddi boyut kazanması ve yonca kuru otunun 1.3 TL'ye çıkması ile bölgede yonca otu üretimine ilgi ekim alanını da artırmıştır. Bölgede fazla sayıda yonca çeşidi tohumluk olarak satılmaya başlamıştır.

Bölgede baraj ve göletlere yakın arazilerde sulu, imkânı olmayan yerlerde ise kıraç koşullarda yoncadan yeterli ot verimi alınmaktadır. Kırklareli koşullarında sulu ve susuz koşullarda devam eden araştırmada susuz koşullardaki uygulamadan, yılda 5 tonu geçen yeşil ot verimi alındığı ve tahıl üretimi ile mukayese edilir duruma geldiği bilinmektedir. İklim değişikliği nedeni ile bölgedeki bahar yağışlarının 20 gün gecikme ile yağmaya başladığı konu uzmanları tarafından bildirilmektedir. Yağışın yoncanın biçim zamanına tesadüf ettiği dönemlerde ot hasadında gecikme yaşandığı bilinmektedir. Hasat zamanında yaşanan gecikmenin yoncanın verimi ve kalitesine etkisinin belirlenmesi amacı ile planlanan ve Tekirdağ susuz koşullarında yürütülen araştırmada Gözlü-1, Bilensoy-80, Verko, Prosementi ve Plato çeşitleri ekilmiş, iki farklı dönemde (\% 10 ve \% 50 
çiçeklenme) hasat edilmiştir. Elde edilen otun verim ve kalite özellikleri (ham protein, NDF, ADF ve nispi yem değeri) araştırılmıştır.

\section{Materyal ve Yöntem}

Tekirdağ Namık Kemal Üniversitesi, Ziraat Fakültesi, Tarla Bitkileri Bölümünden temin edilen Gözlü-1, Bilensoy-80, Verko, Prosementi ve Plato çeşitleri materyal olarak kullanılmıştır. Deneme 2015-2016 yetiştirme mevsiminde Tekirdağ Namık Kemal Üniversitesi Ziraat Fakültesi Tarla Bitkileri Bölümü Araştırma ve Deneme Alanı'nda kurulmuş, 2016-2017 ve 2017-2018 yetiştirme dönemlerinde alınan sonuçlar değerlendirilmiştir.

Araştırmanın yapıldığ 1 alanın yetiştirme dönemlerindeki aylara ve uzun yıllara ait iklim değerleri Çizelge 1'de verilmiştir.

Çizelge 1. Tekirdağ ilinin uzun yıllar iklim ortalamaları (1939-2018)

\begin{tabular}{lccc}
\hline Aylar & Aylık Toplam Yağış $(\mathrm{mm})$ & Oransal Nem $(\%)$ & Sicaklık $\left({ }^{\circ} \mathrm{C}\right)$ \\
\hline KASIM & 75.4 & 83.7 & 11.0 \\
ARALIK & 81.5 & 83.6 & 7.1 \\
OCAK & 68.8 & 84.1 & 4.7 \\
ŞUBAT & 54.1 & 82.1 & 5.4 \\
MART & 54.4 & 81.2 & 7.3 \\
NiSAN & 40.9 & 78.8 & 11.8 \\
MAYIS & 36.7 & 77.3 & 16.8 \\
HAZİRAN & 37.9 & 74.2 & 21.3 \\
TEMMUZ & 22.8 & 70.6 & 23.8 \\
AĞUSTOS & 13.3 & 71.2 & 23.8 \\
EYLÜL & 33.6 & 74.8 & 20.0 \\
EKİM & 62.4 & 81.5 & 15.4 \\
\hline Toplam & 581.8 & & \\
\hline
\end{tabular}

(Anonim, 2018a).

Çizelge 2.Tekirdağ ili 2016-2018 yetiştirme dönemine ait iklim verileri

\begin{tabular}{lcccccc}
\hline \multirow{2}{*}{ Aylar } & \multicolumn{2}{c}{ Aylık Toplam Yağış $(\mathrm{mm})$} & \multicolumn{2}{c}{ Oransal Nem (\%) } & \multicolumn{2}{c}{ Sicaklık $\left({ }^{\circ} \mathrm{C}\right)$} \\
\cline { 2 - 7 } & $2016-2017$ & $2017-2018$ & $2016-2017$ & $2017-2018$ & $2016-2017$ & $2017-2018$ \\
\hline KASIM & 67.2 & 45.2 & 83.1 & 76.6 & 11.7 & 12.1 \\
ARALIK & 52.8 & 113.8 & 80.7 & 76.3 & 9.6 & 6.18 \\
OCAK & 107.0 & 67.6 & 84.5 & 85.6 & 1.9 & 6.6 \\
ŞUBAT & 38.8 & 93.7 & 81.8 & 86.1 & 6.4 & 7.3 \\
MART & 32.1 & 78.7 & 82.5 & 85.8 & 9.0 & 9.8 \\
NISAN & 61.1 & 20.5 & 77.7 & 76.4 & 11.1 & 14.0 \\
MAYIS & 16.7 & 36.7 & 76.5 & 79.2 & 16.8 & 18.5 \\
HAZİRAN & 44.3 & 75.9 & 78.1 & 72.6 & 21.9 & 22.3 \\
TEMMUZ & 52.2 & 98.0 & 69.7 & 69.5 & 24.1 & 25.1 \\
AĞUSTOS & 16.6 & 0.0 & 66.7 & 63.1 & 25.1 & 26.0 \\
EYLÜL & 5.1 & 23.1 & 70.8 & 66.1 & 21.6 & 21.8 \\
EKİM & 59.8 & 48.2 & 77.3 & 75.9 & 15.0 & 16.7 \\
\hline Toplam & 553.7 & 701.4 & & & & \\
\hline
\end{tabular}

(Anonim, 2018b).

Araştırmanın yürütüldüğü ilk y1l 553.7 mm, 2. y1l ise 701.4 mm yağış düşmüştür. İkinci yıl düşen yağış1 kış dönemi ile yaz sonunda yoğunlaşmıştır. Oransal nem Haziran ve Temmuz ayı yağışları nedeni ile yükselmiştir. İkinci yıl Ocak ayı ilk yıla göre daha 1lıman geçmiştir (2018b).

Deneme alanına ait toprakların analiz sonuçları incelendiğinde (Çizelge 3), Toprağın killi-tınlı yapıda, nötr pH' da olduğu, organik madde bakımından fakir, azot ve fosfor oranının düşük, potasyum açısından yüksek, kireç miktarının düşük, magnezyum, demir, bakır, çinko, mangan bakımından yeterli olduğu saptanmıştır.

Araştırmanın yapıldığı yetiştirme dönemlerinde deneme alanı topraklarının bazı fiziksel ve kimyasal özellikleri Tekirdağ Ticaret Borsası Toprak Analiz Laboratuvarında yapılmış (Anonim, 2018a) ve ilgili sonuçlar Çizelge 3 ’te verilmiştir. Araştırma, tesadüf blokları deneme desenine göre 
faktöriyel düzende 3 tekrarlamalı olarak susuz koşullarda ve gübre uygulanmadan yürütülmüştür. Araştırmada her parsel $20 \mathrm{~cm}$ aralığında 5 m uzunluğunda 6 sıradan oluşmuştur. Tohumlar $2 \mathrm{~kg} / \mathrm{da}$ ekim normu sağlanacak şekilde 6 Kasım 2015 tarihinde her sıraya el ile ekilmiştir (Demiroğlu ve ark., 2008). Yabancı ot mücadelesi çapa ile yapılmıştır. Tesis yılında biçimler dikkate alınmamıştır.

Çizelge 3. Araştırma yeri toprağına ait fiziksel ve kimyasal özellikler

\begin{tabular}{lccc}
\hline & Birim & $2016-2017$ & $2017-2018$ \\
\hline $\mathrm{pH}$ & & 7.58 & 7.55 \\
Tuz & $\%$ & 0.02 & 0.02 \\
Kireç & $\%$ & 0.65 & 0.63 \\
İşba & $\%$ & 42 & 41 \\
Organik Madde & $\%$ & 1.71 & 1.63 \\
Toplam Azot (N) & $(\mathrm{ppm})$ & 0.14 & 0.11 \\
Fosfor (P) & $(\mathrm{ppm})$ & 8.92 & 8.40 \\
Potasyum (K) & $(\mathrm{ppm})$ & 296.49 & 290.73 \\
Kalsiyum (Ca) & $(\mathrm{ppm})$ & 3440.1 & 3571.4 \\
Magnezyum (Mg) & $(\mathrm{ppm})$ & 117.31 & 116.48 \\
Demir (Fe) & $(\mathrm{ppm})$ & 6.98 & 7.00 \\
Bakır (Cu) & $(\mathrm{ppm})$ & 1.6 & 1.6 \\
Çinko (Zn) & $(\mathrm{ppm})$ & 1 & 0.9 \\
Mangan (Mn) & & 19.63 & 19.58 \\
\hline
\end{tabular}

(Anonim, 2018c).

Çalışmada her yıl 3'er biçim yapılmıştır. Biçimler \%10 Çiçeklenme ve \%50 Çiçeklenme olmak üzere iki farklı dönemde yapılmıştır (Weir ve ark., 1960; Kalu ve Fick, 1983; Probst, 2008). Araştırmanın ilk yılında ilk biçim 30 Mayıs'ta son biçim ise 22 Eylül'de alınmıştır. İkinci yılda ise ilk biçim hava sıcaklığına bağlı olarak 22 Mayıs'ta, son biçim ise 2 Ekim'de yapılmıştır.

Araştırmada bitki boyu her biçimden önce her parselden rastgele seçilen 10 bitkide toprak yüzeyi ile sürgün ucunun üst noktası arasındaki mesafe $\mathrm{mm}$ bölmeli cetvel ile ölçülmüş, ortalaması $\mathrm{cm}$ olarak kaydedilmiştir (Saruhan ve Kuşvuran, 2011).

Parsel yeşil ot verimleri için sıra başı ve sonundan $0.5 \mathrm{~cm}$ 'lik bölüm, hasat öncesi biçilerek deneme dışı bırakılmıştır. Kalan bölüm $\left(4.8 \mathrm{~m}^{2}\right)$ parsel hasat alanı olarak tamamı biçilmiş ve $0.01 \mathrm{~g}$ hassas terazide (Radwag) tartılarak parsel verimleri, sonrasında ise dekar verimleri belirlenmiştir.

Biçim yapıldıktan sonra her parselden rastgele alınan $0.5 \mathrm{~kg}$ 'lık bitki örnekleri kurutma dolabında $70{ }^{\circ} \mathrm{C}$ 'de 48 saat kurutulup, daha sonra 24 saat oda koşullarında sabit ağırlığa gelinceye kadar bekletilmiştir (Akyıldız, 1968). Daha sonra kurutulmuş bitki örnekleri hassas terazi ile tartılmıştır.

Çalışmada kullanılan örnekler ham protein analizi için ilk olarak laboratuvar tipi değirmende (Seedburo, USA) $0.5 \mathrm{~mm}$ elek çapında ögütülmüştür. Öğütülen yonca otu örneklerden her tekerrür için $0.25 \mathrm{~g}$ örnek alınmış ve temiz ve özel kâğıtlara konularak mikro Kjeldahl yöntemi ile azot içerikleri belirlenmiştir. Belirlenen azot miktarı 6.25 ile çarpılarak ham protein oranları bulunmuştur (Akyıldız, 1984).

Yonca çeşitlerine ait ot örneklerinin NIR Spectroskopy (Spectrastar 2400 D, Unity Scientfic, Amerika) cihazında $50 \mathrm{~g}$ numune, cihazın döner kap modülüne konulmuş ve NDF ve ADF oranları örneklerin 48 ayrı noktasından 1200-2400 nm arasında yapılan okuma ile belirlenmiş̧tir. Her bir okuma 3 kez tekrarlanmıştır. Nispi yem değeri Rivera ve Parish (2010)'a göre belirlenmiştir.

\section{1. İstatistiki analizler}

İstatistiksel hesaplamalar deneme planına uygun olarak TARİST paket programında (Açıkgöz ve ark., 1994) analiz edilmiş ve araştırmada incelenen özelliklerin ortalama değerleri arasındaki farkların istatistiki anlamda önemlilikleri, MSTAT paket programı (Anonim, 1982) kullanılarak LSD testi ile belirlenmiştir. 


\section{Bulgular ve Tartışma}

\subsection{Bitki boyu (cm):}

İki yıl devam eden ve \% 10 ve \% 50 çiçeklenme olmak üzere iki farklı biçim zamanında ve yılda üç kez biçilen yonca çeşitlerinin bitki boyu değerleri ile önemlilik grupları Çizelge 4 ve 5 'te verilmiştir.

Çizelge 4. Farklı dönemlerde biçilen yonca çeşitlerinin bitki boyu $(\mathrm{cm})$ değerleri ve önemlilik grupları (2016-2017)

\begin{tabular}{|c|c|c|c|c|c|c|c|c|c|c|c|c|}
\hline \multirow{3}{*}{ Çeşitler } & \multicolumn{9}{|c|}{ Biçim Dönemi } & \multirow{3}{*}{$\begin{array}{c}\text { \%10 } \\
\text { Çiçek } \\
\text { Ort. }\end{array}$} & \multirow{3}{*}{$\begin{array}{c}\text { \%50 } \\
\text { Çiçek } \\
\text { Ort. }\end{array}$} & \multirow{3}{*}{ Ort. } \\
\hline & \multicolumn{3}{|c|}{ 1. Biçim } & \multicolumn{3}{|c|}{ 2. Biçim } & \multicolumn{3}{|c|}{ 3. Biçim } & & & \\
\hline & $\% 10$ & $\% 50$ & Ort. & $\% 10$ & $\% 50$ & Ort. & $\% 10$ & $\% 50$ & Ort. & & & \\
\hline Gözlü-1 & 83.63 & 91.33 & 87.48 & 80.96 & 83.63 & 82.29 & 58.50 & 61.30 & 59.90 & 74.36 & 78.75 & $76.55 \mathrm{ab}$ \\
\hline Bilensoy-80 & 74.40 & 95.67 & 85.03 & 90.60 & 74.40 & 82.50 & 54.20 & 50.96 & 52.58 & 73.06 & 73.67 & 73.37ab \\
\hline Prosementi & 81.43 & 83.67 & 82.55 & 93.53 & 81.43 & 87.48 & 60.86 & 49.96 & 55.41 & 78.60 & 71.68 & 75.14ab \\
\hline Plato & 70.63 & 77.00 & 73.81 & 90.40 & 70.53 & 80.46 & 54.86 & 49.96 & 52.42 & 71.96 & 65.83 & $68.89 \mathrm{~b}$ \\
\hline Verko & 85.50 & 97.00 & 91.25 & 87.33 & 85.50 & 86.41 & 67.86 & 62.83 & 65.34 & 80.23 & 81.77 & $81.00 \mathrm{a}$ \\
\hline Ort. & $79.11 \mathrm{~b}$ & 88.93a & $84.02 \mathrm{a}$ & $88.56 a$ & $79.11 b$ & $83.83 a$ & $59.25 c$ & $55.00 \mathrm{c}$ & $57.12 b$ & 75.64 & 74.34 & 74.99 \\
\hline
\end{tabular}

LSD: biçim dönemi:6.241**; çeşit: $8.057^{* *}$; biçim dönemi x biçim zamanı int: $8.771^{* *}$.

2016-2017 yetiştirme döneminde araştırmanın ilk yılında (2016-2017), 5 farklı yonca çeşidi iki farklı zamanda (\% 10 ve \% 50) ve $3 \mathrm{kez}$ biçilmiştir. Verilerin değerlendirilmesi ile elde edilen varyans analiz sonuçlarına göre; çeşitler arası fark, biçim dönemleri arası fark ile biçim dönemi x biçim zamanı interaksiyonu önemli bulunmuştur (Çizelge 4). Çeşitlerin bitki boyu değerleri incelendiğinde; Verko $(81.00 \mathrm{~cm})$ çeşidi ilk sırada yer alırken, Gözlü-1 $(76.55 \mathrm{~cm})$, Bilensoy-80 $(73.37 \mathrm{~cm})$ ve Prosementi $(75.14 \mathrm{~cm})$ çeşitleri ikinci grupta yer almıştır. Plato $(68.89 \mathrm{~cm})$ çeşidi ise son grupta yer almıştır (Çizelge 4). Araştırmanın ilk yılında (2016-2017) biçim dönemi açısından yapılan değerlendirmede; 1 . biçim $(84.02 \mathrm{~cm})$ ve 2 . biçimde $(83.83 \mathrm{~cm})$ belirlenen bitki boyu değerleri 3. biçimden $(57.12 \mathrm{~cm})$ yüksek bulunmuştur (Çizelge 4).

Biçim dönemi x biçim zamanı interaksiyonunda; en fazla boylanmanın 1. biçimde \% 50 çiçeklenme zamanında $(88.93 \mathrm{~cm})$ ve 2 . biçimde \% 10 çiçeklenme zamanında $(88.56 \mathrm{~cm})$ yapılan boy ölçümlerinde belirlenmiştir. En az boylanma ise 3. biçimde \% 10 çiçeklenme zamanı $(59.25 \mathrm{~cm})$ ile \% 10 çiçeklenme zamanında $(55.00 \mathrm{~cm})$ belirlenmiş̧ir. İlk iki biçimde serin ve nemli koşullar nedeni ile yonca çeşitlerinin bitki boylarında artış saptanmıştır. 3. biçim döneminde yaşanan sıcaklık artışı ve gelişme döneminde düşen yağışın yetersizliği nedeni bitki boyunda yükselme olmamıştır (Çizelge 4).

Araştırmanın ikinci yılında yapılan boy ölçümlerinin değerlendirilmesi ile elde edilen varyans analiz sonuçlarına göre; çeşitler arası fark, biçim dönemleri arası fark, biçim zamanları arası fark ile biçim dönemi x biçim zamanı interaksiyonu istatistiki açıdan önemli bulunmuştur. Araştırmanın ikinci yılına (2017-2018) ait bitki boyu (cm) ortalama değerler ve önemlilik grupları Çizelge 5'te verilmiştir.Verko $(52.12 \mathrm{~cm})$ çeşidi ilk sırada yer alırken, Gözlü-1 $(49.53 \mathrm{~cm})$ ve Prosementi $(47.08$ $\mathrm{cm})$ çeşitleri ikinci grupta yer almıştır. Plato $(41.89 \mathrm{~cm})$ ise en az boylanan çeşit olmuştur.

Biçim dönemi açısından incelendiğinde; en fazla boylanmanın 1. biçimde $(57.77 \mathrm{~cm})$ olduğu, 2. biçim $(41.71 \mathrm{~cm})$ ve 3 . biçimde $(41.47 \mathrm{~cm})$ ise, birbirine yakın değerler saptanmıştır.

Biçim zamanı düzeyinde yapılan değerlendirmede; \% 50 çiçeklenmede $(50.47 \mathrm{~cm}) \% 10$ çiçeklenme $(43.50 \mathrm{~cm})$ zamanına göre daha yüksek boylu bitkiler biçilmiştir (Çizelge 5).

Araştırmanın 2. yılında verilerin değerlendirilmesi ile elde edilen varyans analiz sonuçlarına göre; çeşitler arası fark, biçim dönemleri arası fark ile biçim dönemi x biçim zamanı interaksiyonu önemli bulunmuştur (Çizelge 5).

Araştırmanın 2. yılında bitki boyuna ait sonuçların değerlendirilmesi ile biçim dönemi x biçim zamanı interaksiyonunda; en fazla boylanmanın $(60.60 \mathrm{~cm}) 1$. biçimde, $\% 50$ çiçeklenme zamanında, en az boylanma ise $(35.35 \mathrm{~cm}) 3$. biçim \%10 çiçeklenme zamanında olduğu belirlenmiştir.

Çeşit $\mathrm{x}$ biçim dönemi interaksiyonu açısından yapılan değerlendirmede; en fazla boylanmanın 1. biçimde Verko $(66.70 \mathrm{~cm})$ çeşidinde olduğu, yine 1. biçimde Gözlü-1 $(63.86 \mathrm{~cm})$ çeşidinin ikinci sırada yer aldığ saptanmıştır (Çizelge 5). 
Çizelge 5. Farklı dönemlerde biçilen yonca çeşitlerinin bitki boyu $(\mathrm{cm})$ değerleri ve önemlilik grupları (2017-2018)

\begin{tabular}{|c|c|c|c|c|c|c|c|c|c|c|c|c|}
\hline \multirow{3}{*}{ Çeşitler } & \multicolumn{9}{|c|}{ Biçim dönemi } & \multirow{3}{*}{$\begin{array}{c}\% 10 \\
\text { Çiçek } \\
\text { Ort. }\end{array}$} & \multirow{3}{*}{$\begin{array}{c}\% 50 \\
\text { Çiçek } \\
\text { Ort. }\end{array}$} & \multirow{3}{*}{ Ort. } \\
\hline & \multicolumn{3}{|c|}{ 1. Biçim } & \multicolumn{3}{|c|}{ 2. Biçim } & \multicolumn{3}{|c|}{ 3. Biçim } & & & \\
\hline & $\% 10$ & $\% 50$ & Ort. & $\% 10$ & $\% 50$ & Ort. & $\% 10$ & $\% 50$ & Ort. & & & \\
\hline Gözlü-1 & 60.36 & 67.36 & 63.86ab & 43.83 & 43.15 & 43.49cd & 32.40 & 50.04 & $41.22 \mathrm{~cd}$ & 45.53 & 53.52 & 49.53ab \\
\hline Bilensoy-80 & 52.90 & 59.23 & $56.06 \mathrm{~b}$ & 31.53 & 39.83 & $35.68 \mathrm{~d}$ & 36.10 & 46.36 & 41.23cd & 40.18 & 48.47 & $44.33 \mathrm{bc}$ \\
\hline Prosementi & 53.35 & 58.20 & $55.77 \mathrm{~b}$ & 41.85 & 42.42 & $42.13 c d$ & 39.83 & 46.82 & 43.32cd & 45.01 & 49.15 & $47.08 \mathrm{ab}$ \\
\hline Plato & 44.85 & 48.05 & $46.45 c$ & 38.20 & 42.95 & $40.57 \mathrm{~cd}$ & 33.22 & 44.07 & $38.64 \mathrm{~cd}$ & 38.76 & 45.02 & $41.89 \mathrm{c}$ \\
\hline Verko & 63.20 & 70.20 & $66.70 \mathrm{a}$ & 45.65 & 47.70 & $46.67 c$ & 35.22 & 50.73 & $42.97 \mathrm{~cd}$ & 48.02 & 56.21 & $52.12 \mathrm{a}$ \\
\hline Ort. & $54.93 a$ & $60.60 \mathrm{a}$ & $57.77 a$ & $40.21 c$ & $43.21 c$ & $41.71 \mathrm{~b}$ & $35.35 d$ & $47.60 \mathrm{~b}$ & $41.47 \mathrm{~b}$ & $43.50 \mathrm{~b}$ & $50.47 a$ & 46.99 \\
\hline
\end{tabular}

LSD: biçim dönemi: 4.066**; çeşit:5.249**; biçim zamanı:3.320**; biçim dönemi x biçim zamanı int.: 5.713**; biçim dönemi x çeşit int.: 9.034**.

İlk biçimden itibaren 3. biçime kadar devam eden gelişme süreci boyunca bitki boyundaki azalma yoncanın kıraç koşullarda yetiştirilmesinden kaynaklanmaktadır. Baharın ilk dönemlerinde yağış ve sıcaklığın bitki gelişimi için çok uygun olduğu dönem olması sebebi 1. biçimde döneminde gelişme döneminin avantajlı olması nedeni ile boyları birbirine yakın olan yüksek boylu bitkilerde biçim yapılmıştır. 2 . ve 3 . biçimlerde ise sıcaklık artışı ve yağışın azalması ile birlikte bitki boyu giderek azalmıştır.

Elde edilen bulgular; biçim zamanının gecikmesi ile yoncanın bitki boyunun artığını bildiren Chen ve ark. (2013)'nın bulguları (51.3 -76.6 cm ) ile \% 10 ve tam çiçeklenme zamanında ortalama bitki boyunun 57.3 ve $81.9 \mathrm{~cm}$ arasında değiştiğini bildiren Mutlu (2019)'nun araştırma sonuçları ile uyumlu bulunmuştur.

\subsection{Yeşil ot verimi $(\mathrm{kg} / \mathrm{da})$ :}

Araştırmanın ilk yılında (2016-2017) verilerin değerlendirilmesi ile elde varyans analiz sonuçlarına göre çeşitler arası fark, biçim dönemleri arası fark, biçim zamanları arasındaki fark ile biçim dönemi $\mathrm{x}$ biçim zamanı interaksiyonu ve çeşit $\mathrm{x}$ biçim dönemi $\mathrm{x}$ biçim zamanı interaksiyonu önemli bulunmuştur.

Araştırmanın ilk yılına ait yeşil ot verimi $(\mathrm{kg} / \mathrm{da})$ ortalama değerleri ve önemlilik grupları Çizelge 6'da verilmiştir. Çeşit düzeyinde yapılan değerlendirmede; en fazla yeşil ot verimi 5718.21 kg/da ile Gözlü-1 çeşidinden en az verim ise $4526.00 \mathrm{~kg} / \mathrm{da}$ ile Prosementi çeşidinden alınmıştır.

Biçim dönemi açısından incelendiğinde ise; en yüksek verim 2. biçimde $(2911.17 \mathrm{~kg} / \mathrm{da})$, en düşük verim ise, 3 . biçimde $(657.57 \mathrm{~kg} / \mathrm{da})$ alınmıştır. \% 50 çiçeklenme zamanında yapılan biçimlerde elde edilen toplam yeşil ot verimi $5855.85 \mathrm{~kg} / \mathrm{da}$ ile \% 10 çiçeklenme zamanında yapılan biçimlerden elde edilen $4033.68 \mathrm{~kg} / \mathrm{da}$ verime göre yüksek bulunmuştur (Çizelge 6).

Biçim dönemi x biçim zamanı interaksiyonu incelendiğinde; 2. biçimde \% 50 çiçeklenme (3416.66 kg/da) zamanında elde edilen ot veriminin diğer interaksiyonlardan daha yüksek olduğu belirlenmiştir. En düşük verim 3. biçimde \% 10 çiçeklenme $(547.00 \mathrm{~kg} / \mathrm{da})$ zamanında saptanmıştır (Çizelge 6).

Biçim dönemi x zamanı x çeşit interaksiyonu açısından incelendiğinde; 2. biçimde, \% 50 çiçeklenme zamanında biçilen Gözlü-1 (4250.00 kg/da) çeşidi en yüksek yeşil ot verimine sahip iken, 3. biçimde \% 10 çiçeklenme zamanında biçilen Plato çeşidinde $(400.00 \mathrm{~kg} / \mathrm{da})$ en düşük ot verimi belirlenmiştir (Çizelge 6). İkinci biçimin ilk biçim ile üçüncü biçimden yüksek verime sahip olmuştur.

Araştırmanın ikinci yılında yonca çeşitlerinin yeşil ot verimlerinin değerlendirilmesi sonucunda elde edilen varyans analiz tablosu değerlendirilmesi ile biçim dönemleri arası fark, biçim zamanları arasındaki fark ile biçim dönemi $\mathrm{x}$ biçim zamanı interaksiyonu ve çeşit $\mathrm{x}$ biçim dönemi $\mathrm{x}$ biçim zamanı interaksiyonu önemli bulunmuştur.

Yonca çeşitlerinin yeşil ot verim değerleri $(\mathrm{kg} / \mathrm{da})$ ve önemlilik grupları Çizelge 7'de verilmiştir. Çizelge 7'den görüleceği gibi; biçim dönemi açısından yapılan değerlendirmede; 2 . biçimden elde edilen ot veriminin $(1255.27 \mathrm{~kg} / \mathrm{da})$ diğer biçimlerden (1. biçim $952.95 \mathrm{~kg} / \mathrm{da}$; 3. biçim $390.93 \mathrm{~kg} / \mathrm{da}$ ) daha yüksek olduğu saptanmıştır. Yaz sıcaklı̆̆ının artması ve yağışların yoncanın ihtiyaç duyduğu dönemde düşmemesi nedeniyle en az verim son biçimde alınmıştır.

Biçim zamanı dikkate alındığında ise \% 50 çiçeklenme (1021.02 kg/da) döneminde yapılan geciktirilmiş biçimin, \% 10 çiçeklenme $(703.15 \mathrm{~kg} / \mathrm{da})$ dönemine göre daha yüksek verime sahip olduğu belirlenmiştir (Çizelge 7). 
Biçim dönemi x biçim zamanı interaksiyonu incelendiğinde ise; 2 . biçimde $\% 50$ çiçeklenme döneminde alınan verim (1490.55 kg/da) diğer interaksiyonlardan daha yüksek olmuştur. Bu konuda en düşük verim $(327.35 \mathrm{~kg} / \mathrm{da}) ; 3$. biçimde \% 10 çiçeklenme döneminde yapılan biçimlerden elde edilmiştir (Çizelge 7).

Devam eden süreçte; biçim dönemi $\mathrm{x}$ biçim zamanı x çeşit interaksiyonunda en yüksek ot verimi 1. biçimde \% 50 çiçeklenme döneminde Gözlü-1, çeşidinde $(1666.67 \mathrm{~kg} / \mathrm{da})$, en az verimin ise, 3. biçimde \% 10 çiçeklenme döneminde yapılan biçimde Bilensoy- $80(194.81 \mathrm{~kg} / \mathrm{da})$ çeşidinde olduğu saptanmıştır (Çizelge 7). Kıraç koşullarda yürütülen araştırmada üçüncü biçimin yoğun sıcaklara tesadüf etmesi nedeni ile tüm çeşitlerde belirgin verim azalması meydana gelmiştir. Bu konuda Bilensoy-80 diğer çeşitlerden daha fazla etkilenmiştir.

Toplam yeşil ot verimlerine ait değerler biçim zamanı bakımından incelendiğinde; \% 50 çiçeklenme döneminde biçilen (3063.06 kg/da) yoncalardan \% 10 çiçeklenme dönemine (2109.45 $\mathrm{kg} / \mathrm{da}$ ) göre daha fazla yeşil ot alınmıştır (Çizelge 7).

Elde edilen sonuçların en yüksek ot verimini çeşide göre, yoncanın farklı gelişme döneminde elde eden Bulur (2000)'dan farklı, \% 10 çiçeklenme döneminde elde ettiğimiz yeşil ot veriminin aynı gelişme döneminde biçim yapan, Altınok ve Karakaya (2002) bulguları ile uyumlu olduğu saptanmıştır. Haymana koşullarında farklı biçim zamanlarının (Vejetatif, tomurcuklanma, \%10 çiçeklenme ve çiçeklenme dönemi sonu ve bakla bağlama) ot verimine etkisinin araştırıldığ 1 çalışmada en yüksek verimin $4732.2 \mathrm{~kg} / \mathrm{da}$ ile tam çiçeklenme döneminde alındığını, ancak daha kaliteli ot eldesi için \%50 çiçeklenme döneminin daha uygun olduğunu bildiren Mutlu (2019)'nun sonuçları ile benzer bulunmuştur. Yonca geniş adaptasyon yeteneği ile farklı koşullara uyum sağlama yeteneği ile farklı bölge ve koşullarda biçim zamanına bağlı olarak geç biçimin yeşil ot veriminin yüksek olması doğaldır.

\subsection{Kuru Ot Verimi (kg/da)}

Araştırmanın ilk yılında yonca çeşitlerinin kuru ot verimlerine ait araştırma varyans analiz sonuçlarının değerlendirilmesi ile biçim dönemleri arası fark ${ }^{\text {(Ort.) }}$, biçim dönemleri arası fark ${ }^{\text {(Top.) }}$, biçim zamanları arası fark ile biçim dönemi x biçim zamanı interaskiyonu istatistiki açıdan önemli bulunmuştur.

Araştırmanın ilk yılında (2016-2017) farklı dönemlerde biçilen yonca çeşitlerinin kuru ot verimi $(\mathrm{kg} / \mathrm{da})$ değerleri ve önemlilik grupları Çizelge 8'de verilmiştir.

Kuru ot verimi bakımından biçim dönemleri arası farkın istatistiki olarak önemli olduğu, en yüksek kuru ot veriminin 2. biçimde $(561.66 \mathrm{~kg} / \mathrm{da})$, en düşük kuru ot verimi ise 1 . biçimde $(212.77$ $\mathrm{kg} / \mathrm{da}$ ) belirlenmiştir (Çizelge 8).

\% 50 çiçeklenme zamanında alınan ortalama kuru ot verimi $(384.31 \mathrm{~kg} / \mathrm{da}), \% 10$ çiçeklenme zamanına göre daha yüksek (279.10 kg/da) olmuştur (Çizelge 8). Toplam kuru ot verimi değerlendirildiğinde yine \% 50 çiçeklenmede belirlenen kuru ot verimi $(1152.93 \mathrm{~kg} / \mathrm{da}), \% 10$ çiçeklenme zamanına (837.30 kg/da) kıyasla daha yüksek bulunmuştur (Çizelge 8).

Biçim dönemi x biçim zamanı interaksiyonunda en yüksek verimin (774.99 kg/da) 2. Biçimde, $\% 50$ çiçeklenmede, en düşük verimin ise $(114.66 \mathrm{~kg} / \mathrm{da}) 3$. biçimde $\% 50$ çiçeklenme zamanında olduğu saptanmıştır (Çizelge 8).

Araştırmanın ikinci y1lında yonca çeşitlerinin kuru ot verimlerinin değerlendirilmesi sonucunda elde edilen varyans analiz sonuçlarına göre çeşitler arası fark, biçim dönemleri arası fark, biçim zamanları arasındaki fark ile çeşit x biçim zamanı interaksiyonu önemli bulunmuştur.

Araştırmanın ikinci yılında (2017-2018) kuru ot verimi $(\mathrm{kg} / \mathrm{da})$ değerlerine ilişkin veriler ve önemlilik grupları Çizelge 9'da verilmiştir. Çizelge 9'dan görüleceği gibi, en yüksek kuru ot verimi Verko (694.14 kg/da) ve Gözlü-1 (657.60 kg/da) çeşitlerinde, en düşük verim $(451.62 \mathrm{~kg} / \mathrm{da})$ ise Plato çeşidinde belirlenmiştir (Çizelge 9).

Biçim dönemlerine bakıldığında ilk $(221.33 \mathrm{~kg} / \mathrm{da})$ ve ikinci biçimin kuru ot verimi $(253.53$ $\mathrm{kg} / \mathrm{da}) 3$. biçimin veriminden $(102.27 \mathrm{~kg} / \mathrm{da})$ yüksek bulunmuştur.

Biçim zamanlarına bakıldığında; \% 50 çiçeklenme zamanında hasat edilen yonca çeşitlerinin ortalama kuru ot verimi $212.22 \mathrm{~kg} / \mathrm{da}$, \% 10 çiçeklenmede ise $172.53 \mathrm{~kg} / \mathrm{da}$ olarak belirlenmişsir (Çizelge 9). Biçim zamanlarında elde edilen toplam kuru ot verimine bakıldığında yine \%50 
çiçeklenme zamanında yapılan biçimde elde edilen $636.66 \mathrm{~kg} / \mathrm{da}$ kuru ot verimi, \% 10 çiçeklenmede elde edilen $517.59 \mathrm{~kg} / \mathrm{da}$ verimden yüksek ve istatistiki olarak önemli bulunmuştur.

Çeşit x biçim zamanı interaksiyonunda biçim ortalaması bazında en yüksek kuru ot verimi \% 50 çiçeklenmede biçilen Gözlü-1 çeşidi $(263.01 \mathrm{~kg} / \mathrm{da})$ ile \% 10 çiçeklenme zamanında biçilen Verko (257.03 kg/da) çeşidinde belirlenmiştir. En az verimin ise \% 10 çiçeklenme zamanında (124.62 kg/da) Plato çeşidinde olduğu saptanmıştır (Çizelge 9).

Çeşit x biçim zamanı interaksiyonunda elde edilen en yüksek toplam kuru ot verimi \% 50 çiçeklenme zamanında biçilen Gözlü-1 çeşidi $(789.30 \mathrm{~kg} / \mathrm{da})$ ile \% 10 çiçeklenme zamanında biçilen Verko $(771.09 \mathrm{~kg} / \mathrm{da})$ çeşidinde belirlenmiştir. En az verim \% 10 çiçeklenme zamanında biçilen (373.86 kg/da) Plato çeşidinde saptanmıştır (Çizelge 9).

Yağış rejiminin ilk yıl yoncanın gelişmesine uygun olduğu, ikinci yıl ise daha fazla yağmur alınmasına rağmen zamansız yoğun yağmurlar sorun oluşturmuş ve kuru ot üretimini olumsuz yönde etkilemiştir.

Elde edilen bulgular, en yüksek kuru ot verimini çeşide göre, yoncanın farklı gelişme döneminde elde eden Bulur (2000)'un sonuçları ile benzer bulunurken, en yüksek kuru ot verimini çiçeklenme başlangıcında tespit eden Altınok ve Karakaya (2002), Yolcu ve ark. (2006) ile Milic ve ark. (2014)'nın sonuçlarından farklı bulunmuştur. Gelişme dönemi ilerledikçe, yoncanın kuru ot veriminin yükseldiğini bildiren Weir ve ark. (1960), Mala ve Fadlalla (2013), Chen ve ark. (2013) ve Mutlu (2019)'nun bulguları bizim sonuçlarımızla uyumlu bulunmuştur. Trakya bölgesinde Kırklareli koşullarında benzer konularda yürüyen araştırmalardan elde edilen kuru ot verimi, bizim sonuçlarımızı destekler niteliktedir. 
Çizelge 6. Farklı dönemlerde biçilen yonca çeşitlerinin yeşil ot verimi (kg/da) değerleri ve önemlilik grupları (2016-2017)

\begin{tabular}{|c|c|c|c|c|c|c|c|c|c|c|c|c|c|c|c|}
\hline \multirow{3}{*}{ Çeşitler } & \multicolumn{9}{|c|}{ Biçim Dönemi } & \multirow{3}{*}{$\begin{array}{l}\% 10 \\
\text { Çiçek } \\
\text { Ort. }\end{array}$} & \multirow{3}{*}{$\begin{array}{l}\% 50 \\
\text { Çiçek } \\
\text { Ort. }\end{array}$} & \multirow{3}{*}{$\begin{array}{c}\text { Biçim } \\
\text { zamanı } \\
\text { Ort. }\end{array}$} & \multirow{3}{*}{$\begin{array}{l}\% 10 \\
\text { Çiçek } \\
\text { Top. }\end{array}$} & \multirow{3}{*}{$\begin{array}{l}\% 50 \\
\text { Çiçek } \\
\text { Top. }\end{array}$} & \multirow{3}{*}{$\begin{array}{l}\text { Toplam } \\
\text { verim } \\
\text { Ort. }\end{array}$} \\
\hline & \multirow{2}{*}{\multicolumn{3}{|c|}{$\begin{array}{c}1.1 \mathrm{BCCl \textrm {Im }} \\
\% 10\end{array}$}} & \multirow{2}{*}{\multicolumn{3}{|c|}{$\begin{array}{l}\text { 2. DICIIII } \\
\% 50\end{array}$}} & \multirow{2}{*}{\multicolumn{3}{|c|}{$\begin{array}{l}\text { 3. Biçim } \\
\text { Ort. }\end{array}$}} & & & & & & \\
\hline & & & & & & & & & & & & & & & \\
\hline Gözlü-1 & $1035.33 \mathrm{~h}-\mathrm{m}$ & 1983.33efg & 1509.33 & 2344.43def & $4250.00 \mathrm{a}$ & 3297.21 & $593.33 \mathrm{klm}$ & $1230.00 \mathrm{~g}-\mathrm{m}$ & 911.66 & 1324.36 & 2.487 .78 & 1906.07 & 3973.08 & 7463.34 & $5718.21 \mathrm{a}$ \\
\hline Bilensoy-80 & $1339.00 \mathrm{~g}-\mathrm{l}$ & $1333.33 \mathrm{~g}-\mathrm{l}$ & 1336.16 & 2370def & $3333.33 \mathrm{bc}$ & 2851.66 & $483.33 \mathrm{~lm}$ & $520.00 \mathrm{~lm}$ & 501.66 & 1397.44 & 1728.89 & 1563.17 & 4192.32 & 5186.67 & $4689.50 \mathrm{~b}$ \\
\hline Prosementi & $747.33 \mathrm{j}-\mathrm{m}$ & 1630.00f-1 & 1188.66 & 2343def & $3000.00 \mathrm{bcd}$ & 2671.50 & 533.33lm & 798.33I-m & 665.83 & 1207.89 & 1809.44 & 1508.67 & 3623.67 & 5428.32 & $4526.00 \mathrm{~b}$ \\
\hline Plato & 822.00I-m & 1591.66f-j & 1206.83 & $3116.03 \mathrm{bcd}$ & 2750.00cde & 2933.01 & $400.00 \mathrm{~m}$ & $518.33 \mathrm{~lm}$ & 459.16 & 1446.01 & 1619.99 & 1533.00 & 4338.03 & 4859.97 & $4599.00 \mathrm{~b}$ \\
\hline Verko & 1461.33g-k & 1817.00fgh & 1639.16 & 1854.93fgh & $3750.00 \mathrm{ab}$ & 2802.46 & $725.00 \mathrm{j}-\mathrm{m}$ & $774.0 \mathrm{I}-\mathrm{m}$ & 749.53 & 1347.09 & 2113.67 & 1730.38 & 4041.27 & 6341.01 & 5191.14ab \\
\hline Ort. & $1080.99 \mathrm{~d}$ & $1671.06 \mathrm{c}$ & $1376.03 \mathrm{~b}$ & $2405.67 \mathrm{~b}$ & $3416.66 \mathrm{a}$ & $2911.17 \mathrm{a}$ & $547.00 \mathrm{e}$ & 768.13de & $657.57 \mathrm{c}$ & $1344.56 \mathrm{~b}$ & 1951.95a & 1648.26 & $4033.68 \mathrm{~b}$ & $5855.85 \mathrm{a}$ & 4944.78 \\
\hline
\end{tabular}

LSD: çeşit: 268.320*; biçim dönemi: 279.904**; biçim zamanı: 228.541**; biçim dönemi x biçim zamanı int.:393.376**; biçim dönemi x biçim zamanı x çeşit int.: $879.615^{* * *}$.

Çizelge 7. Farklı dönemlerde biçilen yonca çeşitlerinin yeşil ot verimi $(\mathrm{kg} / \mathrm{da})$ değerleri ve önemlilik grupları (2017-2018)

\begin{tabular}{|c|c|c|c|c|c|c|c|c|c|c|c|c|c|c|c|}
\hline \multirow{3}{*}{ Çeşitler } & \multicolumn{9}{|c|}{ Biçim Dönemi } & \multirow{3}{*}{$\begin{array}{l}\% 10 \\
\text { Çiçek } \\
\text { Ort. }\end{array}$} & \multirow{3}{*}{$\begin{array}{l}\text { \%50 } \\
\text { Çiçek } \\
\text { Ort. }\end{array}$} & \multirow{3}{*}{$\begin{array}{c}\text { Biçim } \\
\text { zamanı } \\
\text { Ort. }\end{array}$} & \multirow{3}{*}{$\begin{array}{c}\text { \%10 } \\
\text { Çiçek } \\
\text { Top. }\end{array}$} & \multirow{3}{*}{$\begin{array}{c}\% 50 \\
\text { Çiçek } \\
\text { Top. }\end{array}$} & \multirow{3}{*}{$\begin{array}{c}\text { Toplam } \\
\text { verim } \\
\text { Ort. }\end{array}$} \\
\hline & \multicolumn{3}{|c|}{ 1.Biçim } & \multicolumn{3}{|c|}{ 2. Biçim } & \multicolumn{3}{|c|}{ 3. Biçim } & & & & & & \\
\hline & $\% 10$ & $\% 50$ & Ort. & $\% 10$ & $\% 50$ & Ort. & $\% 10$ & $\% 50$ & Ort. & & & & & & \\
\hline Gözlü-1 & $629.56 \mathrm{gh} 1$ & $1666.67 \mathrm{a}$ & 1148.11 & 33.34efg & $250.00 \mathrm{~b}-\mathrm{e}$ & 1091.67 & $380.14 \mathrm{ij}$ & 459.78j & 419.96 & 674.68 & 1125.48 & 900.08 & 2024.04 & 3376.44 & 2700.24 \\
\hline Bilensoy-80 & $600.00 \mathrm{~g}-\mathrm{j}$ & 1066.67c-f & 833.33 & 866.67e-h & $1666.67 \mathrm{a}$ & 1266.67 & $194.81 \mathrm{ij}$ & $401.41 \mathrm{ij}$ & 298.11 & 553.83 & 1044.91 & 799.37 & 1661.49 & 3134.73 & 2398.08 \\
\hline Prosementi & $966.67 \mathrm{~d}-\mathrm{g}$ & 1133.33b-e & 1050.00 & $900.00 \mathrm{efg}$ & 1494.44ab & $\begin{array}{l}1197.22 \\
\end{array}$ & $407.83 g-j$ & $\begin{array}{l}378.96 \mathrm{ij} \\
\end{array}$ & 393.40 & 758.16 & 1002.24 & 880.20 & 2274.48 & $\begin{array}{l}3006.72 \\
\end{array}$ & 2640.61 \\
\hline Plato & $666.67 f-1$ & $1000.00 \mathrm{c}-\mathrm{g}$ & 833.33 & $1000.00 \mathrm{c}-\mathrm{g}$ & $1666.67 a$ & $\begin{array}{l}1333.34 \\
\end{array}$ & $346.85 i j$ & $\begin{array}{l}601.01 \mathrm{ij} \\
\end{array}$ & 473.93 & 671.17 & 1019.26 & 845.22 & 2013.51 & 3057.78 & 2535.65 \\
\hline Verko & 866.67e-h & 933.30efg & 899.98 & $1400.00 \mathrm{abc}$ & $1375.00 \mathrm{a}-\mathrm{d}$ & $\begin{array}{l}1387.50 \\
\end{array}$ & $307.13 \mathrm{ij}$ & $431.34 \mathrm{ij}$ & 369.24 & 857.93 & 913.21 & 885.57 & 2573.79 & 2739.63 & 2656.71 \\
\hline Ort. & $745.91 c$ & $1159.99 \mathrm{~b}$ & $952.95 \mathrm{~b}$ & $102.000 \mathrm{~b}$ & $1490.55 a$ & $1255.27 \mathrm{a}$ & $327.35 d$ & $454.50 \mathrm{~d}$ & $390.93 c$ & $703.15 \mathrm{~b}$ & $1021.02 \mathrm{a}$ & 862.09 & $2109.45 b$ & $3063.06 a$ & 2586.26 \\
\hline
\end{tabular}

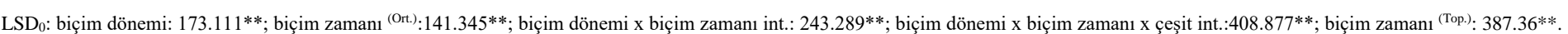

Çizelge 8. Yonca çeşitlerinin kuru ot verimi (kg/da) değerleri ve önemlilik grupları (2016-2017 yetiştirme dönemi)

\begin{tabular}{|c|c|c|c|c|c|c|c|c|c|c|c|c|c|c|c|}
\hline \multirow{3}{*}{ Çeşitler } & \multicolumn{9}{|c|}{ Biçim Dönemi } & \multirow{3}{*}{$\begin{array}{c}\% 10 \\
\text { Çiçek } \\
\text { Ort. }\end{array}$} & \multirow{3}{*}{$\begin{array}{c}\% 50 \\
\text { Çiçek } \\
\text { Ort. }\end{array}$} & \multirow{3}{*}{$\begin{array}{c}\text { Biçim } \\
\text { zamanı } \\
\text { Ort. }\end{array}$} & \multirow{3}{*}{$\begin{array}{c}\% 10 \\
\text { Çiçek } \\
\text { Top. }\end{array}$} & \multirow{3}{*}{$\begin{array}{c}\% 50 \\
\text { Çiçek } \\
\text { Top. }\end{array}$} & \multirow{3}{*}{$\begin{array}{c}\text { Toplam } \\
\text { verim }\end{array}$} \\
\hline & \multicolumn{3}{|c|}{ 1. Biçim } & \multicolumn{3}{|c|}{ 2. Biçim } & \multicolumn{3}{|c|}{ 3. Biçim } & & & & & & \\
\hline & $\% 10$ & $\% 50$ & Ort. & $\% 10$ & $\% 50$ & Ort. & $\% 10$ & $\% 50$ & Ort. & & & & & & \\
\hline Gözlü-1 & 150.67 & 304.13 & 227.4 & 342.00 & 798.33 & 570.16 & 466.66 & 129.06 & 297.86 & 319.77 & 410.50 & 365.14 & 959.33 & 1231.50 & 1095.42 \\
\hline $\begin{array}{l}\text { Bilensoy-80 } \\
\end{array}$ & 200.85 & 220.90 & 210.87 & 366.66 & 700.00 & 533.33 & 233.33 & 97.50 & 165.41 & 266.94 & 339.46 & 303.20 & 800.82 & $\begin{array}{l}1018.38 \\
\end{array}$ & 909.60 \\
\hline Prosementi & 119.54 & 250.06 & 184.8 & 365.00 & 705.00 & 535.00 & 333.33 & 109.56 & 221.44 & 272.62 & 354.87 & 313.74 & 817.86 & 1064.61 & 939.6 \\
\hline Plato & 127.66 & 225.66 & 176.66 & 483.33 & 953.33 & 718.33 & 266.66 & 108.96 & 187.81 & 292.55 & 429.31 & 360.93 & 877.65 & 1287.93 & 1082.79 \\
\hline Verko & 212.58 & 315.70 & 264.14 & 185.00 & 718.33 & 451.66 & 333.33 & 128.23 & 230.78 & 243.63 & 387.42 & 315.52 & 730.87 & 1162.26 & 946.56 \\
\hline Ort. & $162.26 \mathrm{~cd}$ & $263.29 b \mathrm{~b}$ & $212.77 \mathrm{~b}$ & $348.39 \mathrm{~b}$ & $774.99 a$ & $561.69 a$ & $326.66 \mathrm{~b}$ & $114.66 \mathrm{~d}$ & $220.66 \mathrm{~b}$ & $279.10 \mathrm{~b}$ & $384.31 \mathrm{a}$ & 331.71 & $837.30 \mathrm{~b}$ & 1152.93a & 995.13 \\
\hline
\end{tabular}

LSD: biçim dönemi: $86.720^{* *}$; biçim zamanı ${ }^{(0 r t)}: 70.806^{* *}$; biçim dönemi x biçim zamanı:121.875**; biçim zamanı ${ }^{\text {(Top.). }} 212.418^{* *}$. 
Çizelge 9. Yonca çeşitlerinin kuru ot verimi (kg/da) değerleri ve önemlilik grupları (2017-2018 yetiştirme dönemi)

\begin{tabular}{|c|c|c|c|c|c|c|c|c|c|c|c|c|c|c|c|}
\hline \multirow{3}{*}{ Çeşitler } & \multicolumn{9}{|c|}{ Biçim Dönemi } & \multirow{3}{*}{$\begin{array}{c}\% 10 \\
\text { Çiçek } \\
\text { Ort. }\end{array}$} & \multirow{3}{*}{$\begin{array}{c}\% 50 \\
\text { Çiçek } \\
\text { Ort. } \\
\end{array}$} & \multirow{3}{*}{$\begin{array}{c}\text { Biçim } \\
\text { zamanı } \\
\text { Ort. }\end{array}$} & \multirow{3}{*}{$\begin{array}{c}\% 10 \\
\text { Çiçek } \\
\text { Top. }\end{array}$} & \multirow{3}{*}{$\begin{array}{c}\text { \%50 } \\
\text { Çiçek } \\
\text { Top. }\end{array}$} & \multirow{3}{*}{$\begin{array}{c}\text { Toplam } \\
\text { verim }\end{array}$} \\
\hline & \multicolumn{3}{|c|}{ 1. Biçim } & \multicolumn{3}{|c|}{ 2. Biçim } & \multicolumn{3}{|c|}{ 3. Biçim } & & & & & & \\
\hline & $\% 10$ & $\% 50$ & Ort. & $\% 10$ & $\% 50$ & Ort. & $\% 10$ & $\% 50$ & Ort. & & & & & & \\
\hline Gözlü-1 & 200.00 & 266.67 & 233.33 & 266.67 & 366.67 & $\begin{array}{l}316.67 \\
\end{array}$ & 59.55 & 155.69 & 107.62 & 175.40bcd & 263.01a & $219.20 \mathrm{a}$ & $526.20 \mathrm{bcd}$ & 789.30a & $657.60 \mathrm{a}$ \\
\hline Bilensoy-80 & 213.33 & 160.00 & 186.66 & 240.00 & 302.00 & 271.00 & 53.55 & 108.08 & 80.815 & 168.96bcd & 190.02a-d & 179.49ab & 506.88bcd & 570.06a-d & $538.47 \mathrm{ab}$ \\
\hline Prosementi & 120.00 & 280.00 & 200.00 & 200.00 & 263.33 & 231.66 & 89.96 & 134.34 & 112.15 & $136.65 \mathrm{~cd}$ & 225.89ab & 181.27ab & 409.95cd & $677.67 \mathrm{ab}$ & 543.81ab \\
\hline Plato & 160.00 & 200.00 & 180.00 & 160.00 & 230.00 & 195.00 & 53.88 & 99.39 & 76.63 & $124.62 \mathrm{~d}$ & $176.46 \mathrm{bcd}$ & $150.54 \mathrm{~b}$ & $373.86 \mathrm{~d}$ & 529.38bcd & $451.62 \mathrm{~b}$ \\
\hline Verko & 373.33 & 240.00 & 306.66 & 280.00 & 226.67 & 253.33 & 117.78 & 150.50 & 134.14 & $257.03 a$ & 205.72abc & $231.38 \mathrm{a}$ & 771.09a & 617.16abc & 694.14a \\
\hline Ort. & 213.33 & 229.33 & $221.33 a$ & 229.33 & 277.73 & 253.53a & 74.94 & 129.60 & $102.27 \mathrm{~b}$ & $172.53 b$ & $212.22 \mathrm{a}$ & 192.37 & $517.59 \mathrm{~b}$ & $636.66 a$ & 577.11 \\
\hline
\end{tabular}

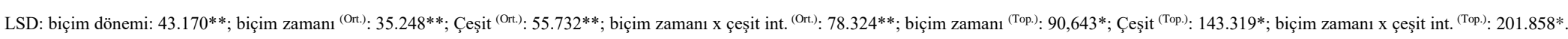




\subsection{Kalite analizleri}

\subsubsection{Protein oranı (\%):}

Araştırmanın ilk yılında yonca çeşitlerinin otundaki protein oranlarına ait varyans analiz sonuçlarına göre biçim dönemleri arası fark önemli bulunmuştur.

Araştırmanın ilk y1lında (2016-2017) yonca çeşitlerinin otundaki protein oranları (\%) ve önemlilik grupları Çizelge 10'da verilmiştir.

Çizelge 10. Farklı dönemlerde biçilen yonca çeşitlerinin protein (\%) değerleri ve önemlilik grupları (2016-2017)

\begin{tabular}{|c|c|c|c|c|c|c|c|c|c|}
\hline \multirow{3}{*}{ Çeşitler } & \multicolumn{6}{|c|}{ Biçim dönemi } & \multirow{3}{*}{$\begin{array}{c}\text { \%10 } \\
\text { Çiçeklenme } \\
\text { Ort. }\end{array}$} & \multirow{3}{*}{$\begin{array}{c}\% 50 \\
\text { Çiçeklenme } \\
\text { Ort. }\end{array}$} & \multirow{3}{*}{ Ort. } \\
\hline & \multicolumn{3}{|c|}{ 2. Biçim } & \multicolumn{3}{|c|}{ 3. Biçim } & & & \\
\hline & $\begin{array}{c}\% 10 \\
\text { Çiçeklenme }\end{array}$ & $\begin{array}{c}\% 50 \\
\text { Çiçeklenme }\end{array}$ & Ort. & $\begin{array}{c}\% 10 \\
\text { Çiçeklenme }\end{array}$ & $\begin{array}{c}\% 50 \\
\text { Çiçeklenme }\end{array}$ & Ort. & & & \\
\hline Gözlü-1 & 20.56 & 20.55 & 20.55 & 21.16 & 21.34 & 21.25 & 20.86 & 20.94 & 20.20 \\
\hline Bilensoy-80 & 20.53 & 20.55 & 20.54 & 22.54 & 23.57 & 23.05 & 21.53 & 22.06 & 21.80 \\
\hline Prosementi & 20.58 & 21.59 & 21.08 & 21.16 & 21.62 & 21.34 & 20.87 & 21.60 & 21.24 \\
\hline Plato & 20.53 & 20.54 & 20.53 & 22.56 & 21.02 & 21.78 & 21.54 & 20.78 & 21.16 \\
\hline Verko & 20.55 & 20.57 & 20.56 & 21.64 & 22.26 & 21.95 & 21.09 & 21.41 & 21.25 \\
\hline Ortalama & 20.55 & 20.76 & $20.65 b$ & 21.81 & 21.96 & $21.87 a$ & 21.18 & 21.36 & 21.13 \\
\hline
\end{tabular}

LSD: biçim dönemi: $0.654 * *$.

2016-2017 yetiştirme döneminde yonca otunun protein oranlarına ilişkin araştırma sonuçları ait biçim dönemi incelendiğinde; 3 . biçimde elde edilen otun protein oranı (\% 21.89) ilk grupta yer almış ve 2. biçimden (\% 20.65) daha yüksek bulunmuştur (Çizelge 10).

Araştırmanın ikinci yılında (2017-2018) protein (\%) oranlarına ait varyans analiz sonuçlarına göre yoncanın biçim zamanı dışında araştırmaya konu faktörler ve interaksiyonları önemli bulunmamıştır. Araştırmanın ikinci yılında (2017-2018) yonca çeşitlerinin otunda belirlenen protein oranlarına ilişkin değerler ve önemlilik grupları Çizelge 11'de verilmiştir.

Çizelge 11. Farklı dönemlerde biçilen yonca çeşitlerinin protein oranları (\%) ve önemlilik grupları (2017-2018)

\begin{tabular}{|c|c|c|c|}
\hline \multirow{3}{*}{ Çeşitler } & \multicolumn{3}{|c|}{ 1.Biçim } \\
\hline & \multicolumn{3}{|c|}{ Biçim dönemi } \\
\hline & \%10 Çiçeklenme & \%50 Çiçeklenme & Ort. \\
\hline Gözlü-1 & 22.54 & 21.17 & 21.85 \\
\hline Bilensoy-80 & 23.99 & 21.25 & 22.62 \\
\hline Prosementi & 23.22 & 20.61 & 21.91 \\
\hline Plato & 21.21 & 20.35 & 20.78 \\
\hline Verko & 22.69 & 21.50 & 22.09 \\
\hline Ort. & 22.73a & $20.97 b$ & \\
\hline
\end{tabular}

LSD: biçim dönemi: $1.281 *$.

2017-2018 yetiştirme döneminde yonca otundaki protein içeriğine (\%) ait araştırma sonuçları biçim zamanı açısından incelendiğinde; \% 10 çiçeklenme zamanındaki protein oranı (\% 22.73), \% 50 çiçeklenme zamanında biçilen yonca otunun protein oranından (\% 20.98) yüksek bulunmuştur (Çizelge 11).

Elde ettiğimiz sonuçların Weir ve ark. (1960), Probst (2008), Mala ve Fadlalla, (2013; \% 2617), Chen ve ark. (2013; \% 25-18.42) ile Mutlu (\% 22.6-25.5) 'nun bulguları ile uyumlu olduğu saptanmıştır.

Erken yapılan biçimlerin daha yüksek protein oranın sahip olması doğaldır. En yüksek protein oranının yoncanın vejetatif döneminde yapılan biçimlerden alınması biçimlerin gecikmesi ile birlikte azalması beklenen bir sonuç olmuştur. 


\subsubsection{NDF oranı (\%):}

Hücre duvarı elemanlarının belirlenmesinde kullanılan yonca otunun NDF oranı, nötr deterjan çözeltide çözünmeyen hemiselüloz, selüloz, lignin, kütin ve silikadan oluşan lifli maddeler olarak tanımlanabilir.

Araştırmanın ilk yılında yonca çeşitlerinin kuru otunun NDF oranlarının değerlendirilmesi sonucunda elde edilen varyans analizine göre biçim dönemleri arası fark, biçim zamanları arasındaki fark ile biçim dönemi x biçim zamanı interaksiyonu önemli bulunmuştur.

Araştırmanın ilk yılında (2016-2017) farklı biçim döneminin yonca otunun kalitesine olan etkisinin belirlendiği çalışmada, 2. biçimde (\% 43.36) belirlenen NDF oranı, 3. biçimden (\% 40.60) yüksek bulunmuştur (Çizelge 12).

Çizelge 12. Farklı dönemlerde biçilen yonca çeşitlerinin NDF (\%) oranları ve önemlilik grupları (2016-2017)

\begin{tabular}{|c|c|c|c|c|c|c|c|c|c|}
\hline \multirow{3}{*}{ Çeşitler } & \multicolumn{6}{|c|}{ Biçim dönemi } & \multirow{3}{*}{$\begin{array}{c}\text { \%10 } \\
\text { Çiçeklenme } \\
\text { Ort. }\end{array}$} & \multirow{3}{*}{$\begin{array}{c}\text { \%50 } \\
\text { Çiçeklenme } \\
\text { Ort. }\end{array}$} & \multirow{3}{*}{ Ort. } \\
\hline & \multicolumn{3}{|c|}{ 2. Biçim } & \multicolumn{3}{|c|}{ 3. Biçim } & & & \\
\hline & $\begin{array}{c}\text { \%10 } \\
\text { Çiçeklenme }\end{array}$ & $\begin{array}{c}\% 50 \\
\text { Çiçeklenme }\end{array}$ & Ort. & $\begin{array}{c}\text { \%10 } \\
\text { Çiçeklenme }\end{array}$ & $\begin{array}{c}\% 50 \\
\text { Çiçeklenme }\end{array}$ & Ort. & & & \\
\hline Gözlü-1 & 43.53 & 43.81 & 43.67 & 37.73 & 43.57 & 40.65 & 40.63 & 43.69 & 42.16 \\
\hline Bilensoy-80 & 43.42 & 43.42 & 43.42 & 39.90 & 44.16 & 42.03 & 41.66 & 43.79 & 42.72 \\
\hline Prosementi & 41.58 & 43.33 & 42.46 & 38.68 & 42.58 & 40.63 & 40.13 & 42.96 & 41.54 \\
\hline Plato & 43.49 & 43.57 & 43.53 & 38.54 & 40.39 & 39.46 & 41.01 & 41.98 & 41.50 \\
\hline Verko & 43.74 & 43.73 & 43.74 & 39.02 & 41.45 & 40.23 & 41.38 & 42.59 & 41.98 \\
\hline Ortalama & $43.15 \mathrm{ab}$ & $43.57 a$ & $43.36 \mathrm{a}$ & $38.77 \mathrm{c}$ & $42.43 \mathrm{~b}$ & $40.60 \mathrm{~b}$ & $40.96 \mathrm{~b}$ & $43.02 \mathrm{a}$ & 41.98 \\
\hline
\end{tabular}

LSD: Biçim dönemi:1.213**; biçim zamanı:1.213**; biçim dönemi x biçim zamanı:0.885**.

2016-2017 yetiştirme döneminde biçim zamanı bakımından incelendiğinde; \% 10 çiçeklenme zamanında biçilen yoncanın NDF oranı (\% 40.96) \% 50 çiçeklenme zamanında yapılan biçime (\% 43.00) göre daha yüksek bulunmuştur. \% 10 çiçeklenme zamanından sonra geçen süre ile birlikte NDF oranının yükseldiği, otun kalitesinin azaldığı belirlenmiştir (Çizelge 12).

Biçim dönemi $x$ biçim zamanı interaksiyonunda en yüksek NDF oranı 2. Biçim döneminde \% 50 çiçeklenme zamanında (\% 43.57), en düşük NDF oranı ise 3. biçimde \% 10 çiçeklenme zamanında (\% 38.77) belirlenmiştir. İkinci biçimden sonra bitkilerin 3. biçim döneminde yağışların bu dönemde yaşanması ve sıcaklığın uygun olması NDF oranını düşürmüş ve daha kaliteli ot elde edilmiştir (Çizelge 12).

Araştırmada kullanılan yonca çeşitlerinin araştırmanın ikinci yılında (2017-2018) NDF (\%) oranlarına ait ortalama değerler ve önemlilik grupları Çizelge 13'te verilmiştir.

2017-2018 yetiştirme döneminde NDF oranları biçim zamanı bakımından incelendiğinde; biçim zamanı geciktikçe örneğin \%10 çiçeklenme zamanında \%38.95 iken, \%50 çiçeklenme zamanında \%47.42'ye yükselmiş ve otun kalitesi olumsuz yönde etkilenmiştir (Çizelge 13).

Otun NDF oranı biçim döneminde yaşanan gecikmeye bağlı olarak yükselmekte ve yonca otunun kalitesini olumsuz etkilemektedir. (Redfearn ve Zhang, 2011; Kazemi ve ark., 2012). NDF oranı hücre duvarının ne kadarının sindirilebileceğini belirleyen kalite indikatörüdür (Marsalis ve ark., 2009). NDF'yi oluşturan selüloz, hemiselüloz ve ligninin ruminantlar tarafindan sindirimi oldukça zordur (Mertens, 2011).

Çizelge 13. Farklı dönemlerde biçilen yonca çeşitlerinin NDF (\%) oranları ve önemlilik grupları (2017-2018)

\begin{tabular}{lccc}
\hline & \multicolumn{2}{c}{ Biçim dönemi } \\
\cline { 2 - 4 } Çeşitler & \multicolumn{3}{c}{ 1. Biçim } \\
\cline { 2 - 4 } & \%10 Çiçeklenme & \%50 Çiçeklenme & Ortalama \\
\hline Gözlü-1 & 38.97 & 49.27 & 44.12 \\
\hline Bilensoy-80 & 40.26 & 46.85 & 43.55 \\
\hline Prosementi & 40.14 & 47.48 & 43.81 \\
\hline Plato & 37.73 & 47.31 & 46.18 \\
\hline Verko & 37.67 & $47.42 \mathrm{a}$ \\
\hline Ortalama & $38.95 \mathrm{~b}$ & & 41.92 \\
\hline
\end{tabular}

LSD: biçim dönemi: $1.941^{* *}$ 
Araştırmamızdan elde edilen NDF oranları; Probst (2008)'un farklı biçim aralıkları ile (25, 30, 35 ve 40 gün) yaptığı araştırmadan elde ettiği sonuçlar (sırası ile \%37.6, 38.0, 38.0 ve 39.3), \%10 çiçeklenme zamanında elde ettiğimiz bulgularla uygunluk gösterirken, \%50 çiçeklenme zamanında biçilen yoncaların NDF oranları sonuçlarımızdan düşük bulunmuştur. Benzer konuda Ankara koşullarında yürütülen araştırmada Mutlu (2019)'nun \% 10 çiçeklenme (\% 48.3) ve tam çiçeklenme döneminde (\%50.8) biçtiği yoncanın NDF oranı bizim bulgularımızdan yüksek bulunmuştur. Çalışmamızda \% 10 çiçeklenme döneminde biçilen yonca otunun, \%50 çiçeklenme zamanında yapılan biçime göre daha kaliteli olduğu literatür bildirişleri ile desteklenmektedir (Redfearn ve Zhang, 2011; Kazemi ve ark., 2012).

Önceki çalışmaların değerlendirilmesi ile ortaya çıkan farklılığın araştırmaların yürütüldüğü lokasyonlardaki iklim ve toprak koşullarındaki farklılıktan kaynaklandığı söylenebilir.

\subsubsection{ADF oranı (\%)}

ADF oranı, asit deterjan lif, bitki hücre duvarında yer alan ve asit deterjan solüsyonlarda çözünmeyen selüloz, lignin, kütin ve silikadan oluşan kaba yemin sindirilme özelliği ve net enerji değerinin belirlenmesine yardımcı olan lifli maddeler olarak tanımlanmaktadır. Kalitenin belirlendiği bu değerlerin pratikte \% 31'in altında olması arzu edilmektedir (Redfearn ve Zhang, 2011; Kazemi ve ark., 2012). Araştırmanın ilk yılında yonca çeşitlerinin kuru otunun ADF oranlarının değerlendirilmesi sonucunda elde edilen varyans analiz sonuçlarına göre biçim zamanları arasındaki fark istatistiki yönden önemli bulunmuştur. Çeşitler arası fark ile biçim dönemleri arasındaki fark ise önemsiz bulunmuştur (Çizelge 14).

Çizelge 14. Farklı dönemlerde biçilen yonca çeşitlerinin ADF (\%) oranları ve önemlilik grupları (2016-2017)

\begin{tabular}{|c|c|c|c|c|c|c|c|c|c|}
\hline \multirow{3}{*}{ Çeşitler } & \multicolumn{6}{|c|}{ Biçim dönemi } & \multirow{3}{*}{$\begin{array}{c}\text { \%10 } \\
\text { Çiçeklenme } \\
\text { Ort. }\end{array}$} & \multirow{3}{*}{$\begin{array}{c}\text { \%50 } \\
\text { Çiçeklenme } \\
\text { Ort. }\end{array}$} & \multirow{3}{*}{ Ort. } \\
\hline & \multicolumn{3}{|c|}{ 2.Biçim } & \multicolumn{3}{|c|}{ 3.Biçim } & & & \\
\hline & $\begin{array}{c}\% 10 \\
\text { Çiçeklenme }\end{array}$ & $\begin{array}{c}\text { \%50 } \\
\text { Çiçeklenme }\end{array}$ & Ort. & $\begin{array}{c}\% 10 \\
\text { Çiçeklenme }\end{array}$ & $\begin{array}{c}\% \text { \%0 } \\
\text { Çiçeklenme }\end{array}$ & Ort. & & & \\
\hline Gözlü-1 & 41.97 & 41.96 & 41.97 & 40.21 & 44.38 & 42.29 & 41.09 & 43.17 & 42.13 \\
\hline Bilensoy-80 & 39.21 & 42.04 & 40.63 & 39.18 & 43.63 & 41.41 & 39.20 & 42.84 & 41.02 \\
\hline Prosementi & 40.14 & 38.33 & 39.24 & 40.44 & 43.31 & 41.88 & 40.29 & 40.82 & 40.56 \\
\hline Plato & 38.55 & 42.95 & 40.75 & 40.06 & 42.56 & 41.31 & 39.30 & 42.75 & 41.03 \\
\hline Verko & 40.94 & 42.44 & 41.69 & 40.83 & 43.06 & 41.94 & 40.80 & 42.75 & 41.82 \\
\hline Ortalama & 40.16 & 41.54 & 40.86 & 40.14 & 43.39 & 41.77 & $40.15 b$ & $42.47 a$ & \\
\hline
\end{tabular}

LSD: biçim zamanı: $2.010^{* *}$

Araştırmanın ikinci yılında 1. biçim döneminde yapılan biçimlerde alınan kuru otun ADF oranlarının değerlendirilmesi sonucunda elde edilen varyans analiz sonuçlarına göre çeşitler arası fark ile biçim zamanları arası fark istatistiki yönden önemli bulunmuştur.

Araştırmanın ikinci yılında (2017-2018) ise ADF (\%) değerleri ve önemlilik grupları Çizelge 15 'te verilmiştir.

2017-2018 yetiştirme döneminde çeşitlerin ADF içerikleri bakımından yapılan değerlendirmede, en yüksek ADF oranı Gözlü-1 çeşidinde (\%42.41), en düşük ise (\% 40.76$)$ ise Verko çeşidinde belirlenmiştir (Çizelge 15).

Yoncada iki farklı dönemde yapılan biçimlerde \% 10 çiçeklenmede yapılan biçimin \% 50 çiçeklenme zamanında yapılan biçime göre daha kaliteli ot ürettiği saptanmıştır. Bulgularımız Doohong (2016) (\%21.5-35.2) ve Probst (2008) (\%25-28.2)' un bulgularından yüksek, Mutlu (2019) (\%47.1-\%50.8)'nun sonuçlarından düşük bulunmuştur. 
Çizelge 15. Farklı dönemlerde biçilen yonca çeşitlerinin ADF (\%) değerleri ve önemlilik grupları (2017-2018)

\begin{tabular}{lccc}
\hline & & \multicolumn{2}{c}{ Biçim dönemi } \\
\cline { 2 - 4 } Çeşitler & & 1. Biçim & \%50 Çiçeklenme \\
\cline { 2 - 4 } & \%10 Çiçeklenme & 44.08 & $42.41 \mathrm{a}$ \\
\hline Gözlü-1 & 40.74 & 43.18 & $41.18 \mathrm{bc}$ \\
Bilensoy-80 & 39.17 & 42.61 & $40.98 \mathrm{bc}$ \\
Prosementi & 39.34 & 44.17 & $41.81 \mathrm{ab}$ \\
Plato & 39.45 & 42.21 & $40.76 \mathrm{c}$ \\
Verko & 39.31 & $43.25 \mathrm{a}$ & 41.43 \\
\hline Ortalama & $39.60 \mathrm{~b}$ & & \\
\hline
\end{tabular}

LSD: biçim zamanı: $0.580^{* *}$, çeșit: $0.964^{* *}$.

Yapılan değerlendirmede Mutlu (2019)'nun elde ettiği otun ADF içeriğinin bizim bulgularımızdan yüksek olduğu saptanmıştır. Çeşit düzeyinde önemli bulunan ADF içeriğinin sahip oldukları genetik yapıdan kaynaklanmaktadır (Katić ve ark., 2009). ADF oranı bakımından önceki çalışmalara göre belirlenen farklılığın araştırmaların yürütüldüğü ekolojik koşulların farklı olmasından kaynaklanabilir.

\subsubsection{Nispi yem değeri (\%):}

Nispi yem değeri yonca otunun kalitesini belirleyen önemli kriterler arasında yer almaktadır. Araştırmanın ilk yılında yonca çeşitlerinin kuru otunun nispi yem değerinin belirlenmesi sonucunda elde edilen varyans analiz sonuçlarına göre biçim dönemleri arasındaki fark istatistiki yönden önemli bulunmuştur (Çizelge 16).

Yonca çeşitlerinin araştırmanın ilk yılında 2. ve 3. biçimde iki farklı dönemde yapılan biçimlerde elde edilen örneklerin nispi yem değerleri ve önemlilik grupları Çizelge $16^{\text {' }}$ da verilmiştir.

2016-2017 yetiștirme döneminde nispi yem değerlerine ait araștırma sonuçları biçim dönemi açısından incelendiğinde; 3. biçimin (129.63), 2. biçimden (122.57) daha yüksek olduğu belirlenmiş̧ir (Çizelge 16).

Çizelge 16. Farklı dönemlerde biçilen yonca çeşitlerinin nispi yem değerleri (\%) ve önemlilik grupları (2016-2017)

\begin{tabular}{|c|c|c|c|c|c|c|c|c|c|}
\hline \multirow{3}{*}{ Çeşitler } & \multicolumn{6}{|c|}{ Biçim dönemi } & \multirow{3}{*}{$\begin{array}{c}\text { \%10 } \\
\text { Çiçeklenme } \\
\text { Ort. }\end{array}$} & \multirow{3}{*}{$\begin{array}{c}\text { \%50 } \\
\text { Çiçeklenme } \\
\text { Ort. }\end{array}$} & \multirow{3}{*}{ Ort. } \\
\hline & \multicolumn{3}{|c|}{ 2.Biçim } & \multicolumn{3}{|c|}{ 3.Biçim } & & & \\
\hline & $\begin{array}{c}\text { \%10 } \\
\text { Çiçeklenme }\end{array}$ & $\begin{array}{c}\% 50 \\
\text { Çiçeklenme }\end{array}$ & Ort. & $\begin{array}{c}\text { \%10 } \\
\text { Çiçeklenme }\end{array}$ & $\begin{array}{c}\% 50 \\
\text { Çiçeklenme }\end{array}$ & Ort. & & & \\
\hline Gözlü-1 & 119.31 & 120.15 & 119.73 & 123.06 & 134.57 & 128.81 & 121.18 & 127.36 & 124.27 \\
\hline Bilensoy-80 & 125.01 & 120.28 & 122.65 & 123.06 & 128.14 & 125.60 & 124.04 & 124.21 & 124.12 \\
\hline Prosementi & 123.71 & 132.98 & 128.35 & 125.47 & 133.81 & 129.64 & 124.59 & 133.39 & 128.99 \\
\hline Plato & 125.66 & 118.58 & 122.12 & 132.95 & 134.92 & 133.93 & 129.30 & 126.75 & 128.03 \\
\hline Verko & 121.28 & 118.73 & 120.01 & 128.25 & 132.11 & 130.18 & 124.77 & 125.42 & 125.09 \\
\hline Ortalama & 122.99 & 122.14 & $122.57 b$ & 126.56 & 132.71 & 129.63a & 124.78 & 127.43 & 126.10 \\
\hline
\end{tabular}

LSD: biçim dönemi: 5.635**.

Çizelge 17. Farklı dönemlerde biçilen yonca çeşitlerinin nispi yem değerleri (\%) ve önemlilik grupları (2017-2018)

\begin{tabular}{|c|c|c|c|}
\hline \multirow{3}{*}{ Çeşitler } & \multicolumn{3}{|c|}{ Biçim dönemi } \\
\hline & \multicolumn{3}{|c|}{ 1. Biçim } \\
\hline & \%10 Çiçeklenme & \%50 Çiçeklenme & Ort. \\
\hline Gözlü-1 & 136.63 & 103.29 & 119.96 \\
\hline Bilensoy-80 & 135.06 & 110.10 & 122.58 \\
\hline Prosementi & 135.01 & 109.17 & 122.09 \\
\hline Plato & 143.49 & 108.13 & 125.81 \\
\hline Verko & 143.95 & 112.92 & 128.44 \\
\hline Ortalama & 138.83a & $108.72 b$ & 123.78 \\
\hline
\end{tabular}

LSD: biçim zamanı: $4.421^{* *}$. 
Araştırmanın ikinci yılında çeşitlerin nispi yem değerlerine ilişkin varyans analiz sonuçlarına göre biçim biçim zamanları arasındaki fark istatistiki yönden önemli bulunurken, çeşitler arası fark önemsiz bulunmuştur (Çizelge 16). 17 'de verilmiştir.

Araştırmanın ikinci yılında (2017-2018) ise NYD değerleri ve önemlilik grupları Çizelge

2017-2018 yetiştirme döneminde NYD içerikleri biçim zamanı bakımından incelendiğinde; \% 50 çiçeklenme döneminde biçilen otun nispi yem değeri (108.72), geç biçim nedeni ile \% 10 çiçeklenme dönemine göre (138.83) daha düşük bulunmuştur (Çizelge 17).

Elde edilen bulgular daha önce aynı konuda çalışmaları bulunan araştırmacıların bulguları ile karşılaştırıldığında; Doohong (2016) (125-195)'nin bulgularına yakın, Probst (2008) (159.1-172.2) ve Mutlu (2019) (147.2-162.5)'nun bulgularından düşük bulunmuştur.

Farklılığın materyal olarak kullanılan çeşitlerden ve sulu koşullarda yürütülen araştırmada yoncanın daha iyi gelişmesi ve daha kaliteli ot üretiminden kaynaklanabilir.

\section{Tartışma ve Sonuç}

Tekirdağ ekolojik koşullarında 2016-2017 ve 2017-2018 döneminde yürütülen ve Gözlü-1, Bilensoy-80, Prosementi, Verko, Plato çeşitlerinin materyal olarak kullanıldığı araştırmada; en yüksek yeşil ot verimi ilk y1l 4188.98 kg/da ile Gözlü-1 çeşidinde ikinci y1l ise $2955.87 \mathrm{~kg} / \mathrm{da}$ ile Verko çeşidinde belirlenmiştir. Biçim dönemleri dikkate alındığında iki yılın ortalaması olarak \% 50 çiçeklenme dönemi (4274.54 kg/da), \% 10 çiçeklenme dönemine göre (3274.40 kg/da) daha fazla yeşil ot verimine sahip olmuştur. Yine iki yıllık ortalama değerlere göre; en yüksek yeşil ot verimi \%50 çiçeklenme döneminde Gözlü-1 çeşidi (4924.20 kg/da) ile onu izleyen Verko çeşidinde (4534.00 $\mathrm{kg} / \mathrm{da}$ ) belirlenmiştir. İklim değişikliğinin daha belirgin yaşandığı dönemde bitkisel üretim kadar hayvansal üretimin de etkileneceği gerçeği kabul edilmelidir. Bu yönde yapılacak çalışmalara yer verilmesi, sonuçlarının da üretici ile paylaşılması önem arz etmektedir.

Tekirdağ susuz koşullarında yapılan araştırmada Gözlü-1 ve Verko çeşidinin \% 50 çiçeklenme zamanında biçilerek en yüksek ot veriminin alındığı saptanmıştır. Ancak arzu edildiği takdirde nispi yem değeri yüksek ot üretimi için Verko ve Gözlü çeşitlerinin \% 10 çiçeklenme döneminde biçilmesi mümkündür. Kaliteli yonca otunun eldesi için kıraç koşullarda daha fazla çeşidin yer aldığı benzer çalışmaların yapılmasının önemli olduğu görüşündeyiz.

\section{Kaynakça}

Açıkgöz, N., Aktaş, M. E., Mokhaddam, A. F. \& Özcan, K. (1994). Tarist an agrostatistical package programme for personel computer. E.Ü.Z.F. Tarla Bitkileri Kongresi, İzmir, Turkey.

Açıkgöz, E. (2001). Yembitkileri. (Yenilenmiş 3. Bask1). Uludağ Üniversitesi Güçlendirme Vakfı Yayın No: 182, Vipaş A. Ş. Yayın No: 58, İstanbul.

Açıkgöz, E. \& Demirel, M. (2021). Van ili İpekyolu ilçesinde üretilen yonca kuru otunun hasattan depolamaya kadar besin madde kompozisyon düzeyindeki değişimin incelenmesi. Yüzüncü Yıl Üniversitesi Tartm Bilimleri Dergisi, 31 (1): 121-132.

Akyıldız A. R. (1968). Yemler Bilgisi Laboratuar Kılavuzu. A. Ü. Zir. Fak. Yayınları No. 358, Ankara.

Aky1ldız, A. R. (1984). Yemler Bilgisi Laboratuvar Kılavuzu (İlave İkinci Baskı). Ankara Üniversitesi Ziraat Fakültesi Yayınları: 895, Uygulama Kılavuzu: 213, Ankara, 227 s.

Altınok, S. \& Karakaya, A. (2002). Forage yield of different alfalfa cultivars under ankara conditions. Turkish Journal of Agricultural Forestry, 26, 11-16.

Anonim. (2018a). T.C. Orman ve Su İşleri Bakanlığı Meteoroloji Genel Müdürlüğü, Tekirdağ İli Uzun Y1llar (1939-2018) Meteorolojik Verileri, Tekirdağ.

Anonim. (2018b). T.C Orman ve Su İşleri Bakanlığı Meteoroloji Genel Müdürlüğü, Tekirdağ İli 20162018 yılları Meteorolojik Verileri, Tekirdağ.

Anonim. (2018c). Tekirdağ Ticaret Borsası Toprak Analiz Laboratuvarı.

Bulur, B. (2000). Farklı biçim zamanlarının bazı yonca çeşitlerinde (Medicago sativa L.) ot verimi ve kalitesi ile bazı morfolojik özellikleri üzerine etkileri (DR). Uludağ Üniversitesi Fen Bilimleri Enstitüsü, Bursa, Türkiye. 
Chen, J. S., Gao, C., Di, G. L., Zhu, R. F. \& Zhang, Y. X. (2013). Effects of cutting on alfalfa yield and quality in Nortest Chine. Journal of Animal and Veterinary 12(2), 253-260.

Demiroğlu, G., Geren, H. \& Avcıŏlu R. (2008). Farklı yonca (Medicago sativa L.) genotiplerinin Ege Bölgesi koşullarına adaptasyonu. Ege Üniv. Zirat Fak. Derg., 45(1), 1-10.

Doohong, M. (2016). Effects of cutting interval between harvests on dry matter yield and nutritive value in alfalfa. American Journal of Plant Sciences, 7, 1226-1231.

Duke J. A. (1983). Handbook of Energy Crops. NewCROPS web site, Purdue University

Dunham, J. R. (1998). Relative feed value measures forage quality. Forage Facts, 41.

Kalu, B. A. \& Fick, G. W. (1983). Morphological stage of development as a predictor of alfalfa herbage quality. Crop Sci. 23, 1167-1172.

Katić S., Milić D., Karagić Đ., Vasiljević S., Glamočić D., \& Jajić I. (2009). Variation of protein, cellulose and mineral content of lucerne as influenced by cultivar and cut. Biotechnology in Animal Husbandry, 25, 1189-1188.

Kazemi, M., Tahmasbi, A. M., Naserian, A. A., Valizadeh, R. \& Moheghi, M. M. (2012). Potential nutritive value of some forage species used as ruminants feed in Iran. African Journal of Biotechnology 11, $12110-12117$.

Mala, A. S. E. E. \& Fadlalla, B. (2013). Effect of stage of cutting alfalfa (berseem) on crude protein content and dry matter yield. ARPN Journal of Science and Technology 3 (10).

Marsalis, M. A., Hagevoort, G. R. \& Lauriault, L. M. (2009). Hay quality, Sampling and Testing. NMSU Cooperative Extension Service Publication. Las Cruces, NM. Circular 6641. November.

Maurie`s, M. (2004). Cours Luzerne, 1e`re partie,_Editions France Agricole, Paris, France.

Mertens, D. (2011). What are the Five Most Important things to Measure in Hay Crops? IN Proceedings, Western Alfalfa \& Forage Conference, Las Vegas. 11-13 December, 2011.

Milic, D., Katic, S., Katanski, S., Dugalic, G., Bokan, N. \& Vasiljevic, S. (2014). Effect of genotype and applied management on alfalfa yield and quality. Ratar. Povrt.51(2).

Mutlu, Z. (2019). Bazı yonca çeşitlerinde farklı biçim zamanı uygulamalarının ot verimi ve kalitesi üzerine etkileri (DR). Ankara Üniversitesi, Fen Bilimleri Enstisütsü, Ankara, Türkiye.

Orloff, B. S. \& Putnam, H. D. (2007). Harvest Strategies for Alfalfa University of California California Alfalfa Workgroup Homepage.

https://alfalfa.ucdavis.edu/IrrigatedAlfalfa/pdfs/UCAlfalfa8299HarvestStrategies free.pdf Erisim Tarihi: 01.08.2020.

Orloff B. S, Putnam D. \& Khaled B. D. (2015). éDrought Strategies For Alfalfa” Df] Drought Tip: Drought Strategies for Alfalfa-California Alfalfa http://anrcatalog.ucanr.edu/ Erisim Tarihi: 01.08 .2020 .

Probst, T.A. (2008). Harvest frequency and cultivar effects on yield, quality, and regrowth rate among new alfalfa cultivars. University of Kentucky Master's Theses. Paper 527.

Putnam, H. D., Robinson, P. \& Petrs, De. Ed. (2008). “Forage Quality and Testing” Extension Specialist, Department of Plant Sciences,. University of California, Divison of agriculture and Natural Resources UCD Alfalfa Workgroup - California Alfalfa Workgroup.

Redfearn, D. \& Zhang, H. (2011). Forage Quality interpretations, Oklahoma cooperative extension service, PSS 2117

Relative feed value and quality index. Pp.16-31 In: Proc. Florida Ruminant Nutrition Symposium, January 10-11, University of Florida, Gainesville.

Rivera D. \& Parish J. (2010). Interpreting forage and feed analysis. Report. 2620, Mississippi State University.

Saruhan, V. \& Kuşvuran, A. (2011). Güneydoğu Anadolu Bölgesi koşullarında bazı yonca (Medicago sativa L.) çeşitleri ve genotiplerinin verim performanslarının belirlenmesi. Ege Üniversitesi Ziraat Fakültesi Dergisi, 48 (2), 131-138.

TÜİK. (2019). Türkiye İstatistik Kurumu İstatistiki Göstergeler. Yem Bitkileri İstatistikleri.

TÜİK. (2020). Türkiye İstatistik Kurumu İstatistiki Göstergeler. Yem Bitkileri İstatistikleri.

Undersander, D., Cosgrove, D., Cullen, E., Craig, G., Marlin, E. R., Mark, R., Sheaffer, C., Glen, Shewmaker, G. \& Sulc, M. (2011). Alfalfa Management Guide” This publication is a joint effort of: University of Wisconsin-Extension, Cooperative Extension Minnesota Extension Service, Uni Published by: American Society of Agronomy, Inc. Crop Science Society of 
America, Inc. Soil Science Society of America, Inc. (C) 2011 by American Society of Agronomy, Inc., Crop Science Society of America, Inc., and Soil Science Society of America, Inc.versity of Minnesota Iowa State University Cooperative Extension Service Alfalfa Management Guide- American Society of Agronomy.

Weir, W. C., Jones, L. G. \& Meyer, J. H. (1960). Effect of cutting interval and stage of maturity on the digestibility and yield of alfalfa. $J$ Anım $S c r$ 19, 5-19.

Veronesi, F., Brummer, E. C. \& Huyghe, C. (2010). Alfalfa. In: Boller, B.; Posselt, U. K.; Veronesi, F. (Eds). Handbook of plant breeding: Fodder crops and amenity grasses, vol 5, Springer Vilela D., 2001. Milk production of cows on alfalfa pasture. Informe Agropecuario, 22 (211), 38-43.

Yolcu, H., Tan, M. \& Serin, Y. (2006). Effects of early cutting time and stubble height on yield and quality in lucerne. New Zealand Journal of Agricultural Research, 49(2), 201-206.

Yüksel, O., Albayrak, S., Türk, M. \& Sevimay, C. S. (2016). Dry matter yields and some quality features of alfalfa (Medicago sativa L.) cultivars under two different locations of Turkey. Süleyman Demirel Üniversitesi Fen Bilimleri Enstitüsü Dergisi 20(2), 155-160. 